\title{
Grain yield and physiological parameters of gas exchange in common bean as a
}

\section{function of copper fertilization}

\author{
Rendimento de grãos e parâmetros fisiológicos de trocas gasosas em feijão em função da \\ fertilização com cobre \\ Rendimiento de los granos y los parámetros fisiológicos del intercambio de gases del frijol en \\ función de la fertilización con cobre
}

Received: 03/24/2021 | Reviewed: 04/02/2021 | Accept: 04/06/2021 | Published: 04/17/2021

\author{
Amanda Magalhães Bueno \\ ORCID: https://orcid.org/0000-0001-8830-1040 \\ Universidade Federal de Goiás, Brazil \\ E-mail: amanda.mabu@gmail.com \\ Rilner Alves Flores \\ ORCID: https://orcid.org/0000-0002-6484-7150 \\ Universidade Federal de Goiás, Brazil \\ E-mail: rilner@ufg.br \\ Aline Franciel de Andrade \\ ORCID: https://orcid.org/0000-0001-8231-553X \\ Universidade Federal de Goiás, Brazil \\ E-mail: alineandrade418@gmail.com \\ Marco Aurélio Pessoa-de-Souza \\ ORCID: https://orcid.org/0000-0002-1367-8510 \\ Universidade Federal de Goiás, Brazil \\ E-mail:mpessoa@ufg.br \\ Nícolas Gomes Pedreira \\ ORCID: https://orcid.org/0000-0001-8915-3326 \\ Universidade Federal de Goiás, Brazil \\ E-mail: ngp.197@gmail.com \\ Leonardo Santos Collier \\ ORCID: https://orcid.org/0000-0002-6911-8037 \\ Universidade Federal de Goiás, Brazil \\ E-mail: leonardo@ufg.br \\ Klaus de Oliveira Abdala \\ ORCID: https://orcid.org/0000-0002-6466-9905 \\ Universidade Federal de Goiás, Brazil \\ E-mail: agroklaus@ufg.br \\ Marcio Mesquita \\ ORCID: https://orcid.org/0000-0001-9399-4478 \\ Universidade Federal de Goiás, Brazil \\ E-mail: marcio.mesquita@ufg.br \\ Glenio Guimarães Santos \\ ORCID: https://orcid.org/0000-0002-0271-9751 \\ Universidade Federal de Goiás, Brazil \\ E-mail: gleniogm@ufg.br
}

\begin{abstract}
Conducting a field study to investigate the effects of foliar and soil fertilization with copper on the nutritional and physiological parameters and grain yield of common bean. The experimental design was a randomized block, in a $2 \mathrm{x}$ 5 factorial scheme. The first factor was the site of application of copper fertilization. The second factor was copper doses: $0,1,2,3$, and $4 \mathrm{~kg} \mathrm{ha}^{-1}$ (6 replicates). The following were evaluated: leaf nitrogen and copper contents, relative chlorophyll index (RCI), gas exchange, photochemical efficiency of photosystem II, and grain yield. The data were subjected to analysis of variance and F test ( $\mathrm{p}$-value $<0.05)$, using the Scott \& Knott for qualitative data and polynomial regression for quantitative data. Leaf $\mathrm{Cu}$ content was higher with soil application (4\% and 28\%), both at 24 and 45 DAE, respectively. Net photosynthesis reached a maximum index of $18.77 \mu \mathrm{mol} \mathrm{m}^{-2} \mathrm{~s}^{-1}$ with foliar Cu fertilization at the dose of $4 \mathrm{~kg} \mathrm{ha}^{-1}$. The application of $2.0 \mathrm{~kg} \mathrm{ha}^{-1} \mathrm{Cu}$ was the one that led to the highest grain yields; however, soil application stood out with a yield about $12 \%$ higher of the foliar. Soil fertilization proved to be more efficient in terms of $\mathrm{Cu}$ absorption and RCI rates, improving grain yield (12\%) in relation to foliar, especially at the dose of $2 \mathrm{~kg}^{-1}$. The dose of $2 \mathrm{~kg} \mathrm{Cu} \mathrm{ha}^{-1}$ provided the best differential profit, reaching US\$ $581.96 \mathrm{ha}^{-1}$ and US\$ $503.01 \mathrm{ha}^{-1}$ for soil
\end{abstract}


and foliar application, respectively.

Keywords: Foliar fertilization; In-furrow fertilization; Micronutrients; Photosynthesis; Physiological quality.

\section{Resumo}

Um estudo de campo foi realizado para investigar os efeitos da adubação com cobre via foliar e no solo e sua influência nos parâmetros nutricionais, fisiológicos, produtivos e econômicos do feijoeiro comum (Phaseolus vulgaris L.). O delineamento experimental foi em blocos ao acaso, em esquema fatorial $2 \times 5$. O primeiro fator foi o local de aplicação da fertilização com cobre. O segundo fator foram as doses de cobre: $0,1,2,3$ e $4 \mathrm{~kg} \mathrm{ha}^{-1}$ (6 repetições). Foram avaliados: teores foliares de nitrogênio e cobre, índice relativo de clorofila (ICR), trocas gasosas, eficiência fotoquímica do fotossistema II e rendimento de grãos. Os dados foram submetidos à análise de variância e teste $\mathrm{F}$ (pvalor $<0,05)$, utilizando-se Scott \& Knott para dados qualitativos e regressão polinomial para dados quantitativos. O teor de $\mathrm{Cu}$ nas folhas foi maior com a aplicação no solo (4\% e $28 \%$ ), aos 24 e 45 DAE, respectivamente. A fotossíntese líquida atingiu índice máximo de $18,77 \mu \mathrm{mol} \mathrm{m}{ }^{-2} \mathrm{~s}^{-1}$ com adubação foliar de $\mathrm{Cu}$ na dose de $4 \mathrm{~kg} \mathrm{ha}^{-1}$. A aplicação de $2,0 \mathrm{~kg} \mathrm{ha}^{-1} \mathrm{Cu}$ foi a que proporcionou os maiores rendimentos de grãos; entretanto, a aplicação no solo se destacou com um rendimento cerca de $12 \%$ superior à foliar. A fertilização do solo mostrou-se mais eficiente em termos de absorção de $\mathrm{Cu}$ e doses de IRC, melhorando o rendimento de grãos (12\%) em relação ao foliar, principalmente na dose de $2 \mathrm{~kg} \mathrm{ha}^{-1}$. A dose de $2 \mathrm{~kg} \mathrm{Cu} \mathrm{ha}^{-1}$ proporcionou o melhor ganho diferencial, atingindo US\$ 581,96 ha ${ }^{-1}$ e US \$ 503,01 ha- ${ }^{-1}$ para aplicação no solo e foliar, respectivamente.

Palavras-chave: Adubação foliar; Adubação em cobertura; Micronutrientes; Fotossíntese; Qualidade fisiológica.

\section{Resumen}

El estudio en la campaña fue realizado para investigar las respuestas de los parámetros nutricionales, fisiológicos, productivos y económicos del frijol común (Phaseolus vulgaris L.) después de la aplicación de fertilizante de cobre, en hojas y suelo. Para el ensayo se empleó un diseño de bloques completo al azar, con arreglo factorial $2 \times 5$ en seis repeticiones. El primer factor fue el tipo de la aplicación de fertilizante. El segundo fue los doses de cobre: 0, 1, 2, 3 y $4 \mathrm{~kg} \mathrm{ha}^{-1}$. Las diferencias entre medias de tratamientos fueron comparadas utilizando variancia y la prueba de $\mathrm{F}$ ( $\mathrm{p}-$ valor $<0,05)$ y los valores cualitativos y la regresión polinomial la prueba Scott \& Knott. Las variables en estudio fueron: los niveles de nitrógeno y cobre en las hojas, el índice relativo de clorofila (ICR), los intercambios de gases, eficiencia fotoquímica de fotosistema II y el rendimiento de granos. La aplicación en suelo fue más responsiva para los niveles de $\mathrm{Cu}(4 \%$ y $28 \%$ ) en las hojas a los 24 y 45 días después de la germinación, respectivamente. La fotosíntesis liquida alcanzó el índice máximo de $18,77 \mu \mathrm{mol} \mathrm{m} \mathrm{m}^{-2} \mathrm{~s}^{-1}$ con fertilización de $\mathrm{Cu}$ de $4 \mathrm{~kg} \mathrm{ha}^{-1}$ en las hojas. La aplicación de 2,0 $\mathrm{kg} \mathrm{Cu} \mathrm{ha}^{-1}$ fue el que proporcionó los más grandes rendimientos de granos; mientras tanto, la aplicación en suelo ha tenido $12 \%$ más expresión que la aplicación en las hojas. La fertilización en suelo demostró ser más eficiente de absorción de $\mathrm{Cu}$ y clorofila (IRC) sobre todo a la dosis de $2 \mathrm{~kg} \mathrm{ha}^{-1}$. Esta misma dosis proporcionó lo mejor gano diferencial, con cerca de US\$ 581,96 ha-1 y US\$ 503,01 ha-1 para la aplicación en suelo y en las hojas, respectivamente.

Palabras clave: Fertilización foliar; Cubrir la fertilización; Micronutrientes; Fotosíntesis; Calidad fisiológica.

\section{Introduction}

Bean is one of the main crops in the world. It is widely consumed in Brazil, mainly for its nutritional characteristics (Oliveira et al., 2012). Species Phaseolus vulgaris L. is the most cultivated species among those of the genus Phaseolus, with Brazil as its largest producer and consumer. The Brazilian harvest of 2019 had a total grain production of 1.9 million tons in 1.62 million hectares of cultivated area, with a yield of 1.20 ton ha $^{-1}$ (CONAB, 2020). Goiás State stood out in this scenario with a grain production 230\% above the Brazilian average in the 2019 harvest (CONAB, 2020).

In Brazil, the bean crop is produced in three annual harvests with high yields, namely: "wet harvest" ( $1^{\text {st }}$ harvest), "dry harvest" ( $2^{\text {nd }}$ harvest), and "winter harvest" ( $3^{\text {rd }}$ harvest) (Silva \& Wander, 2013). In the central region of Brazil, the $3^{\text {rd }}$ harvest (May - June) stands out for its high yield, mainly due to the adopted production system, with appropriate use of chemical fertilizers and irrigation practices (Flores et al., 2017; Flores et al., 2018; Flores et al., 2019), genetic breeding (Pires et al., 2020) and pest control (Santos et al., 2020).

The strategy to withstand stress (biotic or abiotic) is an adequate nutritional balance (Soratto et al., 2004; Flores al., 2017; Flores et al., 2018; Mesquita et al., 2018). The bean crop is nutritionally demanding, especially in relation to micronutrients. Sousa and Lobato (2004) stated that the recommendation for micronutrients in Cerrado soils was limiting, mainly due to the lack of studies on the calibration of soil analysis methods. Furthermore, Cesar and Grando (2006) claimed 
that micronutrients such as copper, zinc, manganese, and boron are involved in the reproductive processes of crops, being decisive for increasing of grain yield and quality.

Concerning to copper usage, some authors considered levels ranging between 3 and $7 \mathrm{mg} \mathrm{dm}^{-3}$ as good or adequate (Carvalho \& Fernandes, 2019). However, it is already noticed that $\mathrm{Cu}$ can reach $98 \%$ when it is trapped in organic matter of the liquid fraction of the soil (Ferreira \& Cruz, 1991). Moreover, copper is bounded with high energy on soil colloids, forming a covalent bond between the copper-complex and the oxygen atom of the water molecule, and creating a kind of specific adsorption being no available to plants uptaking (Brunetto et al., 2018).

In the plant, $\mathrm{Cu}$ assists in electron transport and oxidative responses (Malavolta., 2006; Hänsch \& Mendel, 2009; Marschner, 2012), in mitochondrial respiration (Hänsch \& Mendel, 2009), and in cell wall metabolism (Yruela, 2005). Therefore, nutrition with copper is essential (Floss, 2008) for improving productivity, mainly in crops with greater cultivation restrictions. Copper deficiency can reduce the activity of plastocyanin enzymes, involved in electron transport during redox reaction catalysis by mitochondria and chloroplasts, which are dependent on light in photosynthesis (Cakmak, 2000).

According to (Kerbauy, 2004), the decrease in electron transport reduces the photosynthetic rate, consequently reducing the fixation of $\mathrm{CO}_{2}$ in the form of starch and soluble carbohydrates, leading to yield losses. Thus, adequate supply of copper to crops can increase yield, especially in legumes. In this context, Moreira and Moraes (2019) reported that copper fertilization at the dose of $4 \mathrm{~kg} \mathrm{ha}^{-1}$ increased soybean yield by $12.5 \%$ in comparison to no fertilization.

Adequate supply of copper for common bean cultivation may improve the physiological quality of plants and consequently increase grain yield. However, as it is one of the micronutrients least required by crops (Shabbir et al., 2020), its supply can occur through foliar fertilization, even though $\mathrm{Cu}$ has little mobility via phloem (Brunetto et al., 2018). Thus, the present study evaluates the response of common bean to soil and foliar fertilization with copper, addressing the physiological quality and grain yield of plants cultivated in a sprinkler irrigation system under tropical edaphoclimatic conditions.

\section{Methodology}

The experiment was conducted in the experimental area of the School of Agronomy of the Federal University of Goiás $\left(16^{\circ} 35^{\prime} 48^{\prime \prime} \mathrm{S}\right.$ and $49^{\circ} 16^{\prime} 63^{\prime} \mathrm{W}$, approximately $730 \mathrm{~m}$ of altitude), with an average annual rainfall of $1494.7 \mathrm{~mm}$ (Casaroli et al., 2018). The experiment used a central pivot sprinkler irrigation system, providing a water blade of approximately $304 \mathrm{~mm}$ throughout the cultivation cycle. The study was conducted during the winter harvest (June September) (Silva \& Wander, 2013), a period characterized as dry, with Aw (megathermal) climate according to the Köppen climate classification system (Alvares et al., 2013). The climatic data referring to the period of conduction of the experiment were collected in the meteorological station of EA-UFG, containing monthly rainfall and monthly mean, minimum and maximum temperature (Figure 1).

The soil of the area is classified either as a Latossolo Amarelo Eutrófico típico according to Santos et al. (2018), or as a Ferralsol according to FAO (2014). For the purposes of characterization and analysis of current fertility, soil sampling followed the recommendations proposed by Teixeira et al. (2017), chemical analysis followed the methodology proposed by Silva (2009), and granulometric analysis followed Teixeira et al. (2017), considering the 0.0-0.20 cm soil layer (Table 1).

The soil for planting was prepared using the conventional system. For that purpose, harrowing was performed followed by two-disc plowings ( $30 \mathrm{~cm}$ deep) after 10 days. Planting fertilization followed the indication for the crop based on the initial chemical analysis, as recommended by Sousa \& Lobato (2004). Thus, the following were applied in the planting furrow: $20 \mathrm{~kg} \mathrm{ha}^{-1} \mathrm{~N}, 110 \mathrm{~kg} \mathrm{ha}^{-1} \mathrm{P}_{2} \mathrm{O}_{5}$, and $70 \mathrm{~kg} \mathrm{ha}^{-1} \mathrm{~K}_{2} \mathrm{O}$, in the form of urea, simple superphosphate, and potassium chloride, respectively. At 20 and $40 \mathrm{DAE}, 60 \mathrm{~kg} \mathrm{ha}^{-1} \mathrm{~N}$ as urea was applied in topdressing. 
Figure 1. Monthly rainfall and monthly mean temperature, from June to September 2018, at pivot of the School of Agronomy of the Federal University of Goiás, Goiânia, Brazil.

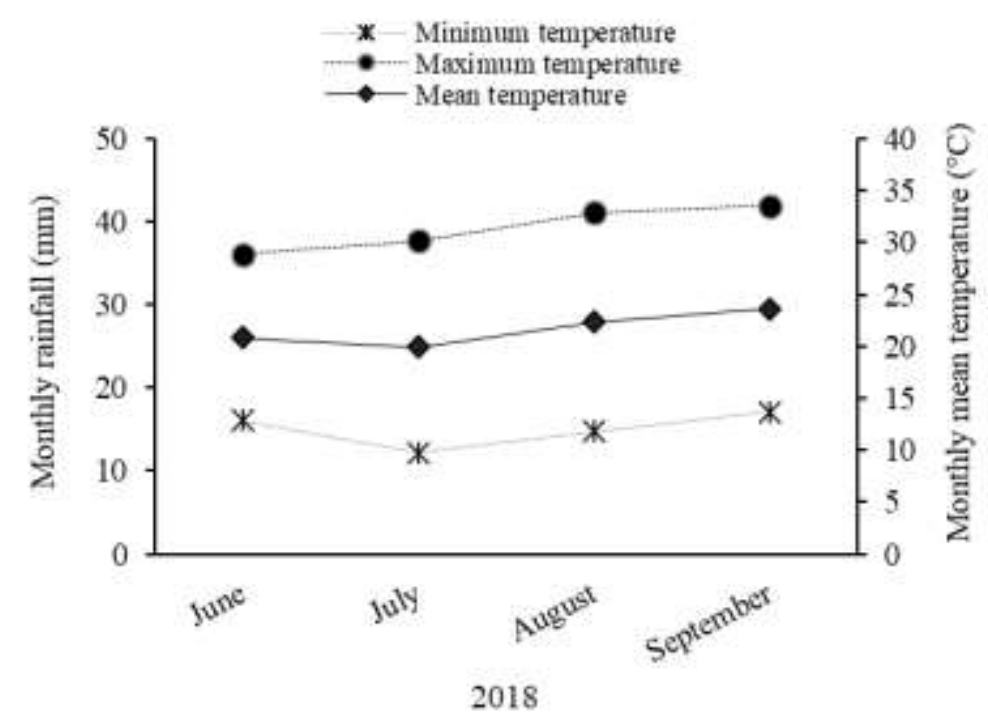

Source: Authors.

Table 1. Soil chemical attributes, at the $0.0-0.20 \mathrm{~m}$ depth, before the installation of the experiment.

\begin{tabular}{|c|c|c|c|c|c|c|c|c|c|}
\hline \multirow{6}{*}{$\begin{array}{c}\text { Depth } \\
0.0-0.20 \mathrm{~m}\end{array}$} & Clay & Sand & Silt & $\mathrm{Cu}$ & $\mathrm{Fe}$ & $\mathrm{Mn}$ & $\mathrm{Zn}$ & \multirow{2}{*}{$\begin{array}{l}\text { O.M. } \\
\mathrm{g} \mathrm{kg}^{-1}\end{array}$} & \multirow{2}{*}{$\frac{\mathrm{pH}}{\left(\mathrm{CaCl}_{2}\right)}$} \\
\hline & \multicolumn{3}{|c|}{--------------\%o-------------- } & $-\overline{---}$ & \multicolumn{3}{|c|}{$---\mathrm{mg} \mathrm{dm}^{-3}$} & & \\
\hline & 13.0 & 58.0 & 29.0 & 1.7 & 70.0 & 8.0 & 4.6 & 20 & 4.5 \\
\hline & $P$ & $\mathrm{~K}$ & $\mathrm{Ca}$ & $\mathrm{Mg}$ & $\mathrm{H}+\mathrm{Al}$ & $\mathrm{Al}$ & CEC & $\mathrm{m}$ & $\mathrm{V}$ \\
\hline & \multicolumn{2}{|c|}{-----mg dm ${ }^{-3}-{ }^{-----}$} & 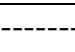 & - & $\mathrm{mol}_{\mathrm{c}} \mathrm{dr}$ & ----- & ----- & \multicolumn{2}{|c|}{-------\%------- } \\
\hline & 0.6 & 22.0 & 1.0 & 0.2 & 5.3 & 0.2 & 6.6 & 13.7 & 19.2 \\
\hline
\end{tabular}

O.M.: Organic Matter; CEC: Cation Exchange Capacity; $\mathrm{m} \%$ and V\%: Aluminum saturation and base saturation, respectively. Source: Authors.

The experimental design was in randomized blocks, in a $2 \times 5$ factorial scheme. The first factor consisted of the site of application of copper-containing fertilizer (foliar and soil application), the second factor consisted of copper doses ( 0 (control), 1, 2, 3, $4 \mathrm{~kg} \mathrm{ha}^{-1}$ copper), with six replicates. Each experimental unit was composed of five $4-\mathrm{m}$ rows spaced $0.45 \mathrm{~m}$ apart.

The fertilizer used, both in the leaf solution and in topdressing, was copper sulfate pentahydrate $\left(\mathrm{Cu}_{2} \mathrm{SO}_{4} .5 \mathrm{H}_{2} \mathrm{O}\right)$, with pH 3.7 - 4.5 and solubility of $50 \mathrm{~g} \mathrm{~L}^{-1}$ at $25^{\circ} \mathrm{C}$ according to Da et al. (2011).

For planting, bean seeds were inoculated by moistening with a $10 \%$ sugar solution, then a peat inoculant was applied containing the Rhizobium tropici strains SEMIA 4077 and SEMIA 4080 and the R. freirei strain SEMIA 4088.

The cultivar used was BRS Estilo, with 95\% germination. Planting was performed to give a population of 150,000 plants ha- ${ }^{-1}$. The seeds were previously treated with the insecticide thiamethoxam $\left(200\right.$ g p.c. $\left.100 \mathrm{~kg}^{-1}\right)$. Planting took place in June 2018, in the $3^{\text {rd }}$ harvest (winter). Manual weedings were carried out during the experiment to avoid possible phytotoxic effects of weeds.

Copper was applied via topdressing and via foliar spray (with the total dose subdivided into three applications at 20, 30, and 40 days after emergence). Both leaf and soil fertilization were subdivided so as to standardize applications and minimize possible phytotoxic effects that could be caused by the application of the total dose. The last portion of the copper dose was applied via leaf at preflowering, stage at which the plant has higher nutritional need and root absorption (Rosolem \& Marubayashi, 1994). Foliar fertilization occurred with the aid of a 20-L back sprayer, with spray solution standardized to $200 \mathrm{~L}$ 
$h a^{-1}$.

The evaluations of relative chlorophyll index (RCI) and leaf copper and nitrogen content were performed at 25 and 45 DAE. The determination of RCI followed the indications of Barbosa Filho et al. (2008) and took place with the aid of a green color index meter (chlorophyll meter) (Falker ${ }^{\circledR}$, model ClorofiLOG CFL 1030). Readings were performed in each experimental unit (plot), in five random plants per unit, considering the first completely expanded leaf from the apex of the main stem for analysis.

Moreover, 20 diagnostic leaves (+3 Leaf - first mature leaf from the tip of the branch) (Souza et al., 2011) were collected per plot. Subsequently, for analysis of $\mathrm{N}$ and $\mathrm{Cu}$ contents, the plant material was washed with distilled water and dried in an oven with forced air circulation at $65 \pm 5{ }^{\circ} \mathrm{C}$ until constant weight, according to the methodology of Silva (2009). The samples were analyzed at the Laboratory of Analysis of Leaves and Organic Compounds (LAFF) of the Federal University of Goiás (UFG).

The physiological parameters of gas exchange and photochemical efficiency of photosystem II were evaluated using a LCpro-SD/iFL portable Infrared Gas Analyzer (IRGA). All evaluations were carried out concurrently, between 9:00 and 11:00 am, under intense irradiation (Alves et al., 2012). The gas exchange parameters analyzed were net photosynthesis (A) ( $\mu \mathrm{mol} \mathrm{m}^{-}$ $\left.{ }^{2} \mathrm{~s}^{-1}\right)$, stomatal conductance (Gs) ( $\left.\mathrm{mol} \mathrm{H} \mathrm{H}_{2} \mathrm{O} \mathrm{m}^{-2} \mathrm{~s}^{-1}\right)$, transpiration (E) $\left(\mathrm{mol} \mathrm{H}_{2} \mathrm{O} \mathrm{m}^{-2} \mathrm{~s}^{-1}\right)$, internal $\mathrm{CO}_{2}$ concentration (Ci) ( $\mu$ mol $\mathrm{mol}^{-1}$ ), and stress index, represented by the photochemical efficiency of photosystem II $\left(\mathrm{Fv} \mathrm{Fm}^{-1}\right)$.

Harvesting was done manually in all experimental units at 100 DAE. For the evaluation of yield, the two central rows were considered, discarding $0.5 \mathrm{~m}$ at each end, totalling a useful area of $0.9 \mathrm{~m}^{2} \mathrm{plot}^{-1}$. After harvesting, the samples were traced manually and cleaned with the aid of a thick sieve. The seeds were weighed for expressing yields in $\mathrm{kg} \mathrm{ha}^{-1}$.

Economic analysis was performed using the partial budget technique, according to Noronha (1987). The method calculates the effects of additional costs and revenues in relation to a baseline, providing differential profits (Dp) as an economic indicator, using the following equation:

$$
\mathrm{Dp}=\mathrm{Rd}-\mathrm{Dc}
$$

Eq.1

Where:

Dp $\left(\right.$ US $\left.\$ h^{-1}\right)=($ differential yield $x$ product price). Differential revenue, calculated from the variation of the yield obtained in each treatment in relation to the control, considered as baseline, multiplied by the historical record of the average price of common bean;

The historical record of bean prices was obtained from prices observed in Brazil in the last 11 years (2009 - 2019), which were deflated to the real values in 2020 and converted into dollars, at the rate of US\$ $=\mathrm{R} \$ 5.08(12 / 12 / 2020)$. Prices were obtained from the Municipal Agricultural Survey (IBEGE-PAM, 2020).

Dc $\left(\right.$ US $\left.\$ h^{-1}\right)=$ Differential cost was calculated directly from the price of the concentration of the product used in each treatment, as these were already differential in relation to the control.

Analyses were performed in relation to the input price, resulting in the differential cost of the input and the cost of the product added to the operational cost of application, which subsequently resulted in the differential cost of operation. The operational cost of application was obtained from Román et al. (2019), who evaluated the operational efficiency of application for different spray volumes. This study allowed to calculate the updated value (US\$ - 2020) of US\$ 15.51 for three applications at spray volume of $100 \mathrm{~L} \mathrm{ha}^{-1}$. Thus, it was possible to calculate from Eq.1 the differential profit (Dp) for each treatment in relation to the control, which was subdivided into Dpi $=$ Differential profit of input and Dpo $=$ Differential profit of operation.

Analysis of variance was performed using the $\mathrm{F}$ test at $5 \%$ probability. When $\mathrm{F}$ values were statistically significant, 
the means from qualitative data were compared using the Scott \& Knott test at 5\% probability. When significant for quantitative data, polynomial regression analysis was performed to demonstrate the interactions of treatments, with models determined by the correlation coefficient of better performance. The AgroEstat software (Barbosa \& Maldonado Júnior, 2015) was used for all statistical analyses.

\section{Results}

The analyses to determine RCI, $\mathrm{N}$ and $\mathrm{Cu}$ were performed at 25 and 45 DAE (Table 2). The results demonstrate that the soil application of copper improves RCI and leaf $\mathrm{Cu}$ levels into the foliar application of copper. Leaf $\mathrm{N}$ content was not altered in the bean plants when it is compared both spraying technology.

Similarly, RCI at $25 \mathrm{DAE}$ and leaf Cu levels (at 25 and $45 \mathrm{DAE}$ ) were also influenced by the application of copper doses, regardless of application site (Table 2). The relative chlorophyll index (RCI) increased by $3 \%$ in relation to the control treatment, while leaf $\mathrm{Cu}$ levels increased to $4 \%\left(16.43 \mathrm{mg} \mathrm{kg}^{-1}\right)$ and $28 \%\left(6.25 \mathrm{mg} \mathrm{kg}^{-1}\right)$, respectively.

Table 2. Relative Chlorophyll Index (RCI), nitrogen $(\mathrm{N})$ and copper $(\mathrm{Cu})$ content in common bean as a function of application site and copper dose.

\begin{tabular}{lcccccc}
\hline \multirow{2}{*}{ Treatment } & \multicolumn{2}{c}{$\mathrm{RCI}\left(\mu \mathrm{g} \mathrm{cm}^{-2}\right)$} & \multicolumn{2}{c}{$\mathrm{N}\left(\mathrm{g} \mathrm{kg}^{-1}\right)$} & \multicolumn{2}{c}{$\mathrm{Cu}\left(\mathrm{mg} \mathrm{kg}^{-1}\right)$} \\
\cline { 2 - 7 } & 25 & 45 & 25 & 45 & 25 & 45 \\
\hline Application site & & & Days After Emergence (DAE) & & \\
Leaf (L) & $57.96 \mathrm{~b}$ & $51.08 \mathrm{a}$ & $5.47 \mathrm{a}$ & $4.70 \mathrm{a}$ & $15.76 \mathrm{~b}$ & $4.87 \mathrm{~b}$ \\
Soil (S) & $59.32 \mathrm{a}$ & $50.54 \mathrm{a}$ & $5.42 \mathrm{a}$ & $4.62 \mathrm{a}$ & $16.43 \mathrm{a}$ & $6.25 \mathrm{a}$ \\
F-test & $4.35^{* *}$ & $4.13^{* *}$ & $0.88^{\text {ns }}$ & $1.52^{\text {ns }}$ & $6.45^{* *}$ & $68.96^{*}$ \\
Copper dose (D) & & & & & & \\
0 & 58.26 & 50.19 & 5.40 & 4.60 & 8.16 & 5.71 \\
1 & 57.80 & 51.45 & 5.49 & 4.78 & 10.91 & 5.40 \\
2 & 56.21 & 50.82 & 5.49 & 4.73 & 12.75 & 5.13 \\
3 & 60.93 & 50.85 & 5.46 & 4.61 & 18.58 & 5.58 \\
4 & 60.00 & 50.74 & 5.39 & 4.59 & 30.08 & 6.00 \\
F-test & $6.51^{*}$ & $2.23^{\text {ns }}$ & $0.79^{\text {ns }}$ & $1.49^{\text {ns }}$ & $878.88^{*}$ & $3.04 * *$ \\
Interaction & & & & & & \\
F-test & $50.25^{*}$ & $8.76^{\text {ns }}$ & $2.64^{\text {ns }}$ & $3.18^{\text {ns }}$ & $109.43^{*}$ & $2.90^{* *}$ \\
\hline Overall mean & 58.64 & 50.81 & 5.44 & 4.66 & 16.10 & 5.56 \\
C.V. (\%) & 4.31 & 2.04 & 3.47 & 5.28 & 6.31 & 11.61 \\
\hline
\end{tabular}

C.V.: coefficient of variation; evaluations performed at 25 and 45 days after seedling emergence, respectively; ns, $*$ and $* *$ - non-significant at $5 \%$, significant at $5 \%$ and $1 \%$ probability by the $\mathrm{F}$ test, respectively. Means followed by the same letter (lowercase) vertically do not differ from each other by the Scott \& Knott means clustering test at 5\% probability. Source: Authors.

When analysing the effect of the interaction between the copper application site and the doses applied, the behavior was similar, influencing RCI at 25 DAE, and leaf copper contents both at 25 and 45 DAE (Table 2). After unfolding the interaction, the adjusted behavior is opposite when comparing the soil application with the foliar application (Figure 2). Foliar copper fertilization increased RCI by $19 \%$ at $25 \mathrm{DAE}$ with the dose of $4 \mathrm{~kg} \mathrm{ha}^{-1}$ in relation to the control treatment (without the addition of fertilizer) (Figure 2). However, although significant, the adjustment showed a correlation coefficient of only $56 \%$. Soil copper fertilization, on the other hand, reduced RCI values by about $12 \%$ with the application of the highest dose in relation to the control treatment (Figure 2). 
Figure 2. Relative chlorophyll index (RCI) as a function of different managements and doses of copper applied to common bean under fertilization. ${ }^{1}$ evaluation performed at $25 \mathrm{DAE}$. * - significant at $5 \%$ probability by the F-test.

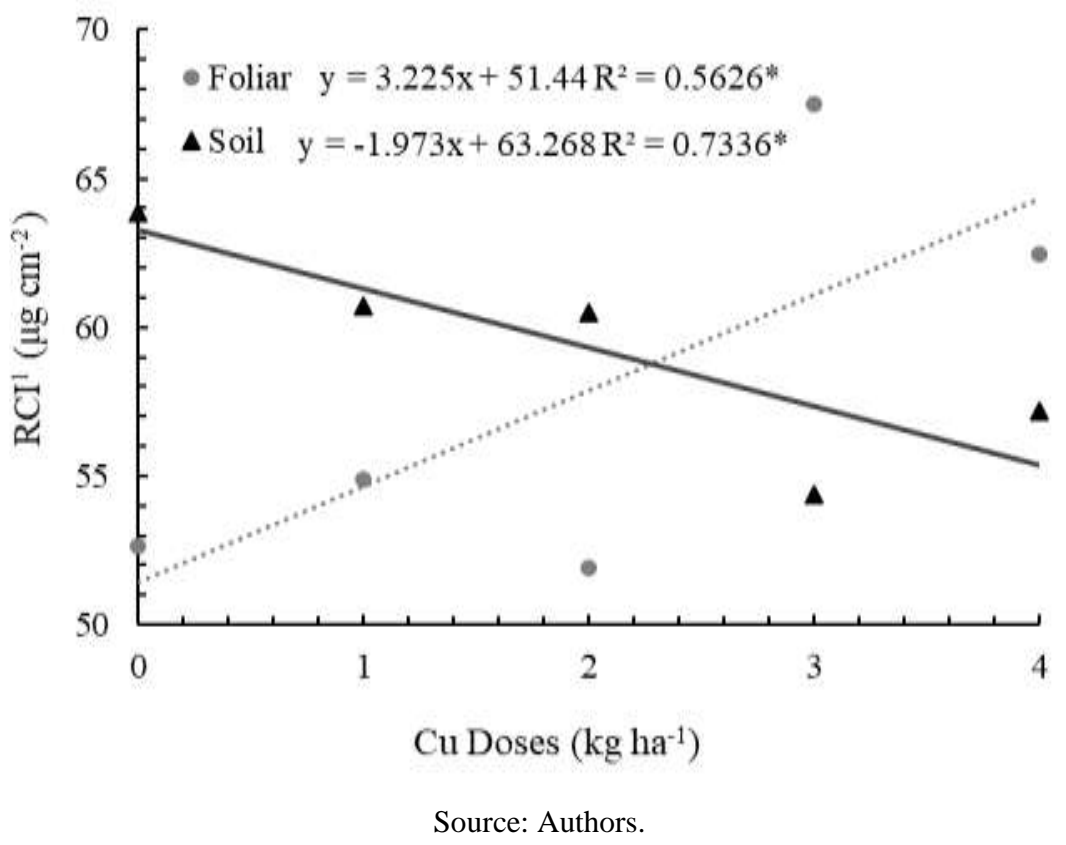

When unfolding the interaction between copper content and the doses applied at $25 \mathrm{DAE}$, it appears that foliar fertilization promoted a linear increase in $\mathrm{Cu}$ content up to the dose of $4 \mathrm{~kg} \mathrm{ha}^{-1}$, reaching $24.66 \mathrm{mg} \mathrm{kg}^{-1}$, that is, an increase of $202 \%$ in relation to the control treatment (Figure 3a). Similarly, leaf $\mathrm{Cu}$ content also increased with soil application, but with quadratic adjustment, with the maximum value $\left(34.5 \mathrm{mg} \mathrm{kg}^{-1}\right)$ also occurring with the application of the highest dose (Figure 3a).

In the evaluation performed at $45 \mathrm{DAE}$, the interaction presented by both forms of $\mathrm{Cu}$ application had quadratic adjustment, with the maximum contents occurring with the application of the highest dose: 5.34 and $6.72 \mathrm{mg} \mathrm{kg}^{-1}$ for foliar and soil application, respectively (Figure 3b).

The physiological parameters of gas exchange (transpiration - E; stomatal conductance - Gs; net photosynthesis - A; internal $\mathrm{CO}_{2}$ concentration - $\mathrm{C} i$; and photochemical efficiency of photosystem II $-F v F^{-1}$ ) evaluated for common beans at 45 DAE are presented in Table 3.

From the evaluation of gas exchange in common bean, physiological quality was assessed at 45 DAE, that is, five days after the last foliar application of copper. The transpiration rate and the net photosynthetic rate were higher with foliar application of copper, being $66 \%$ and $29 \%$ higher in relation to soil application, respectively (Table 3 ).

Regardless of application site, copper significantly increased transpiration rates, stomatal conductance, net photosynthetic rate, and photochemical efficiency of photosystem II, as shown in Table 3. The interaction between application site and copper dose did not affect the transpiration rate. Therefore, the effect of copper application on transpiration in Figure 4 is presented regardless of application site. The figure shows an upward trend, in which transpiration rates increased by about $95 \%$ with the increase in $\mathrm{Cu}$ doses. 
Figure 3. Leaf copper $(\mathrm{Cu})$ content at $25 \mathrm{DAE}$ (a) and $45 \mathrm{DAE}$ (b) in common bean as a function of different managements and doses of copper. ${ }^{1}$ and ${ }^{2}$ evaluations performed at 25 and 45 DAE, respectively. $*$ and $* *$ - significant at $5 \%$ and $1 \%$ probability by the F-test, respectively.
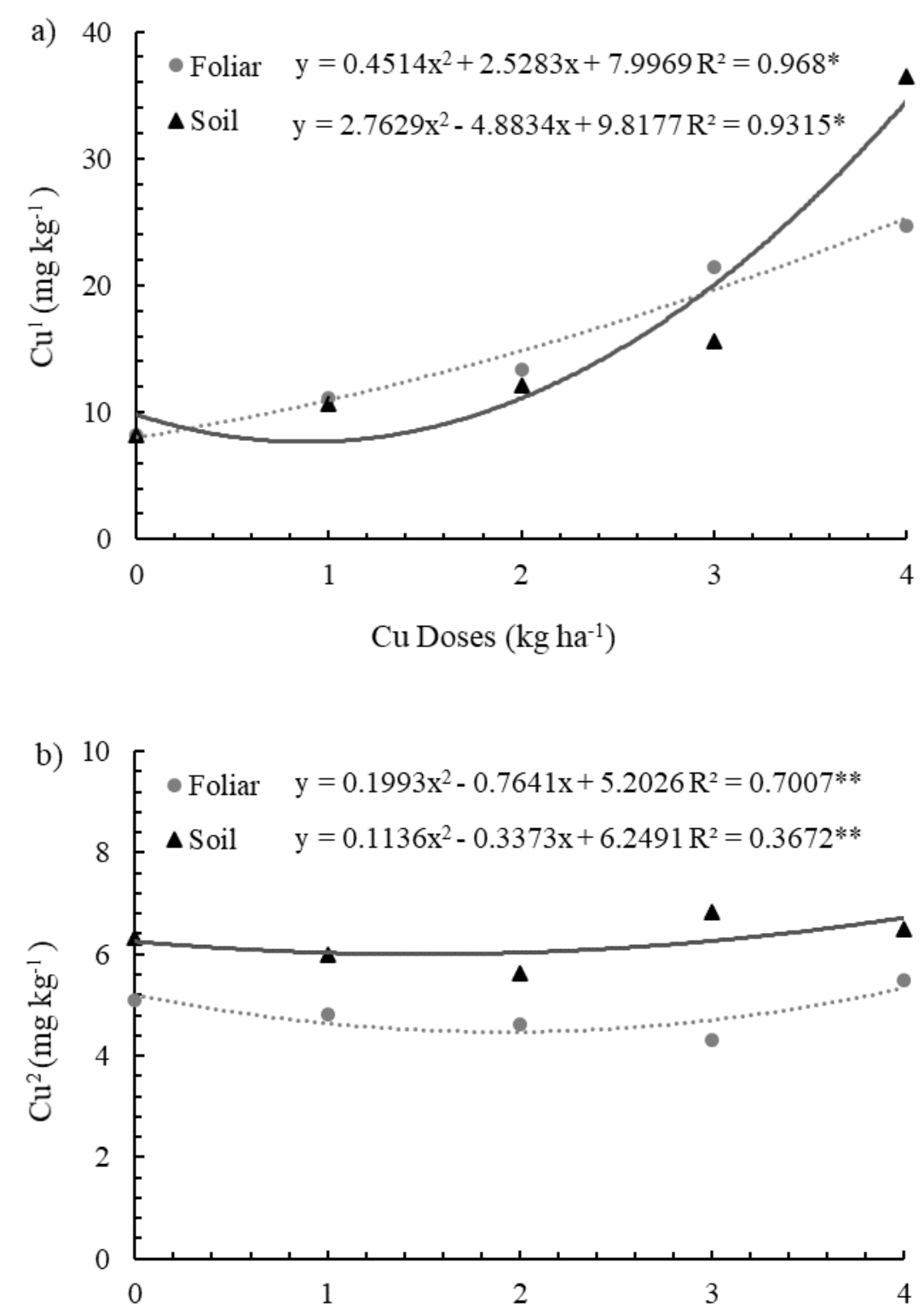

$\mathrm{Cu}$ Doses $\left(\mathrm{kg} \mathrm{ha}^{-1}\right)$

Source: Authors. 
Table 3. Transpiration (E), stomatal conductance (Gs), net photosynthesis (A), internal $\mathrm{CO}_{2}$ concentration (Ci), photochemical efficiency of photosystem II $\left(\mathrm{Fv} \mathrm{Fm}^{-1}\right)$, and grain yield as a function of different managements and doses of copper applied to common bean.

\begin{tabular}{|c|c|c|c|c|c|c|}
\hline Treatment & $E$ & Gs & $\mathrm{A}$ & $\mathrm{Ci}$ & $\mathrm{FV} \mathrm{Fm}^{-1}$ & Yield \\
\hline Application site & $\mathrm{mol} \mathrm{m}^{-2} \mathrm{~s}^{-1}$ & $\mathrm{~mol} \mathrm{~m}^{-2} \mathrm{~s}^{-1}$ & $\mu \mathrm{mol} \mathrm{m} \mathrm{m}^{-2} \mathrm{~s}^{-1}$ & $\mu \mathrm{mol} \mathrm{\textrm {mol } ^ { - 1 }}$ & - & $\mathrm{kg} \mathrm{ha}^{-1}$ \\
\hline Leaf (L) & $8.42 \mathrm{a}$ & $0.27 \mathrm{a}$ & $14.79 \mathrm{a}$ & $270.10 \mathrm{a}$ & $0.77 \mathrm{a}$ & $1336.32 b$ \\
\hline Soil (S) & $5.06 \mathrm{~b}$ & $0.28 \mathrm{a}$ & $11.45 \mathrm{~b}$ & $276.57 \mathrm{a}$ & $0.77 \mathrm{a}$ & $1468.15 \mathrm{a}$ \\
\hline F-test & $309.55^{*}$ & $0.16^{\mathrm{ns}}$ & $109.20 *$ & $0.53^{\text {ns }}$ & $1.93^{\mathrm{ns}}$ & $31.37 *$ \\
\hline \multicolumn{7}{|l|}{ Copper dose (D) } \\
\hline 0 & 4.83 & 0.20 & 7.01 & 287.00 & 0.75 & 1050.98 \\
\hline 1 & 5.61 & 0.26 & 15.37 & 246.62 & 0.77 & 1446.34 \\
\hline 2 & 6.90 & 0.30 & 16.41 & 261.25 & 0.78 & 1964.33 \\
\hline 3 & 7.18 & 0.29 & 16.44 & 261.50 & 0.79 & 1383.77 \\
\hline 4 & 9.17 & 0.33 & 10.38 & 310.31 & 0.75 & 1165.77 \\
\hline F-test & $60.77^{*}$ & $13.86^{*}$ & $139.96 *$ & $6.52^{\mathrm{ns}}$ & $23.53^{*}$ & $179.66 *$ \\
\hline \multicolumn{7}{|l|}{ Interaction } \\
\hline F-test & $1.78^{\mathrm{ns}}$ & $7.24 *$ & $20.93 *$ & $0.20^{\mathrm{ns}}$ & $7.63^{*}$ & $25.60 *$ \\
\hline Overall Mean & 6.74 & 0.28 & 13.12 & 273.33 & 0.77 & $1,402.24$ \\
\hline C.V. $(\%)$ & 8.95 & 13.29 & 7.72 & 10.24 & 1.25 & 6.50 \\
\hline
\end{tabular}

C.V.: coefficient of variation; - evaluations performed 45 days after seedling emergence; ${ }^{\text {ns }}$ and $*$ - non-significant at $5 \%$, significant at $5 \%$ probability by the F test, respectively. Means followed by the same letter (lowercase) vertically do not differ from each other by the Scott $\&$ Knott means clustering test at 5\% probability. Source: Authors.

Figure 4. Transpiration (E) of common bean as a function of different doses of copper, regardless of fertilization management. * - significant at $5 \%$ probability by the F-test.

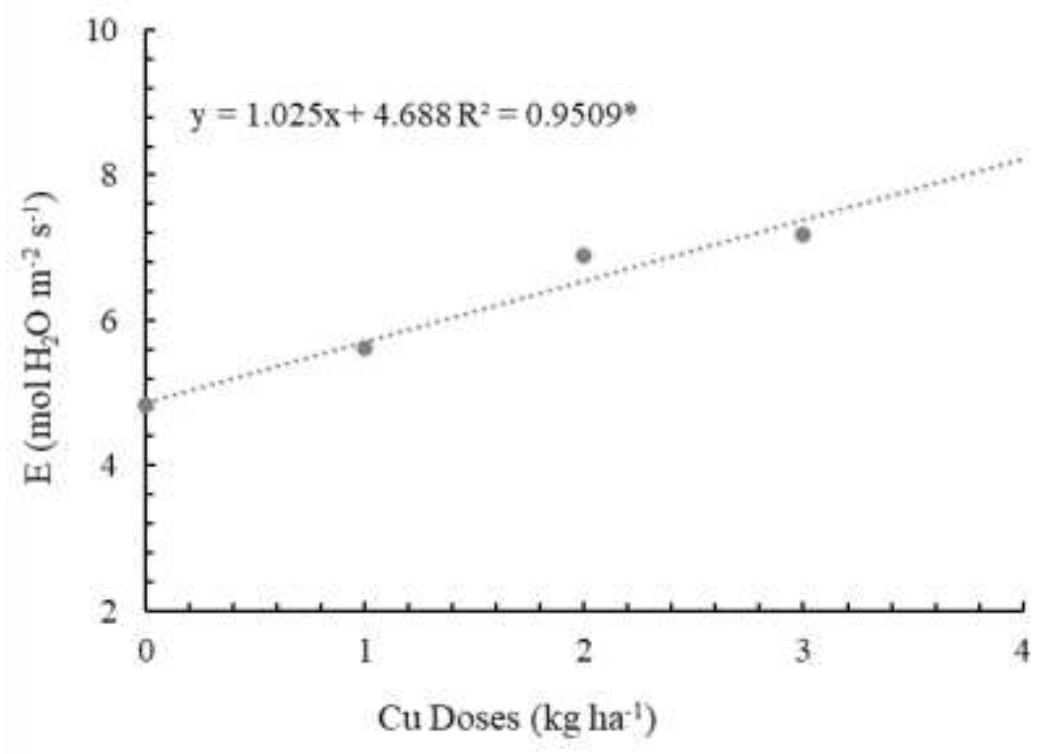

Source: Authors.

The analysis of the interactions between application site and copper dose showed significant effects on stomatal conductance, net photosynthetic rate, and photochemical efficiency of photosystem II (Table 3). 
Figure 5. Stomatal conductance (Gs) (a), net photosynthesis (A) (b), and photochemical efficiency of photosystem II (Fv Fm ${ }^{-1}$ ) (c) of common bean as a function of different managements and doses of copper * - significant at 5\% probability by the F-test.

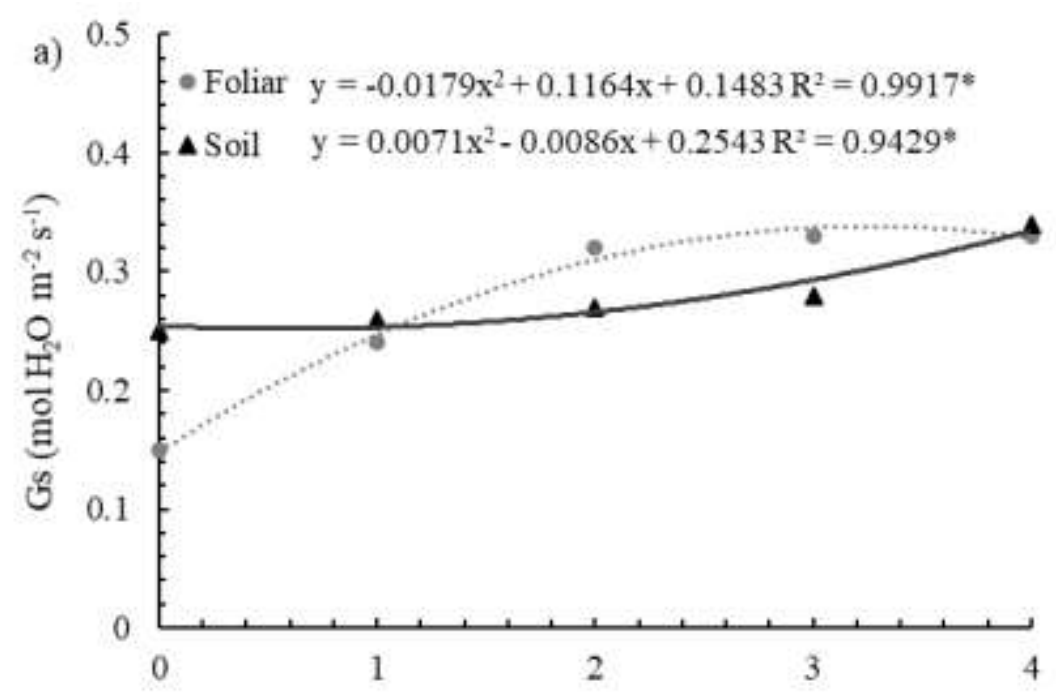

Cu Doses $\left(\mathrm{kg} \mathrm{ha}^{-1}\right)$
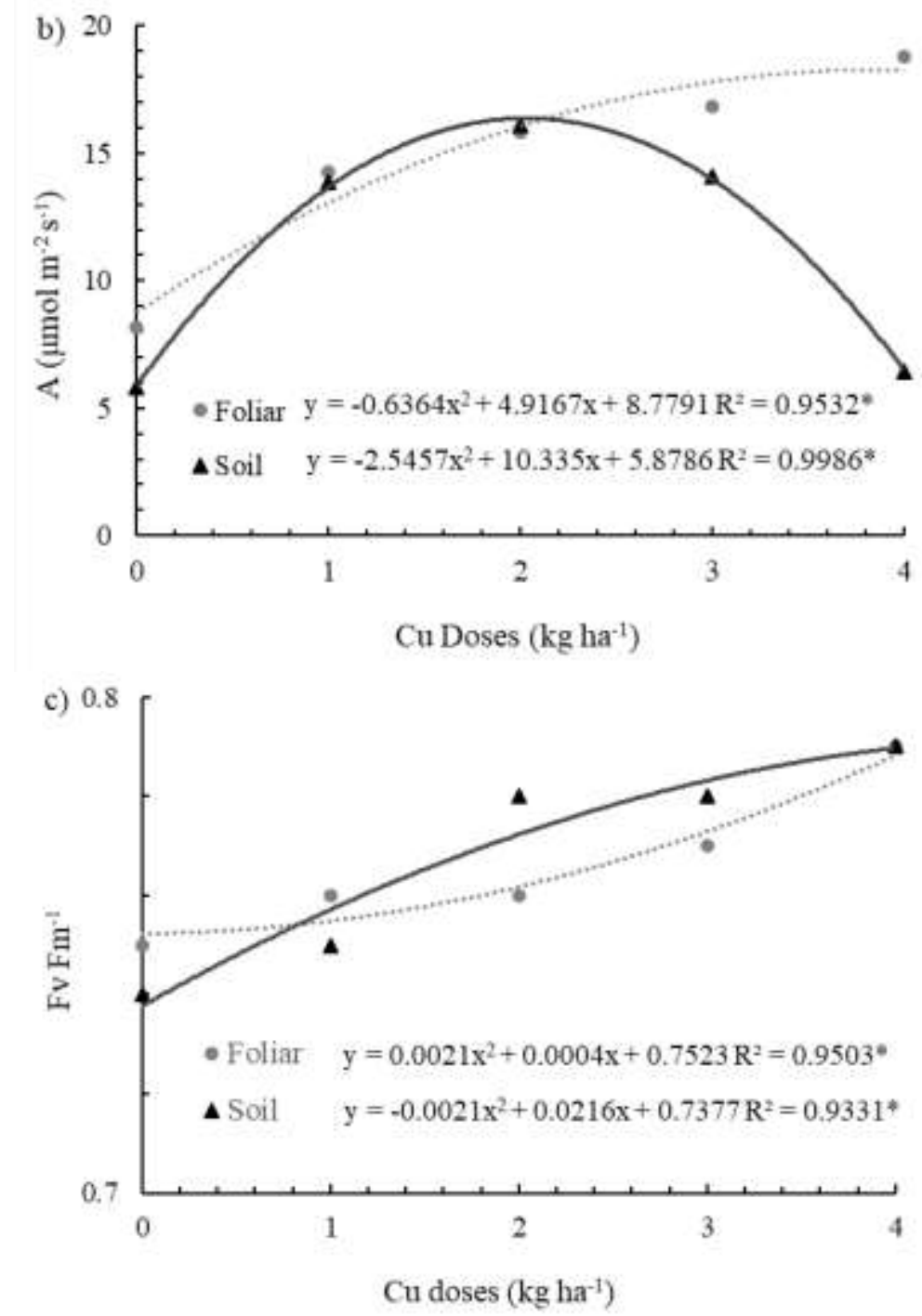

Source: Authors. 
$\mathrm{Cu}$ application promoted a quadratic adjustment for the stomatal conductance of bean plants, with a maximum of 0.34

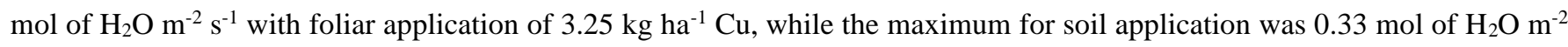
$\mathrm{s}^{-1}$, with $4 \mathrm{~kg} \mathrm{ha}^{-1} \mathrm{Cu}$ (Figure 5a).

Regarding the net photosynthetic rate, both adjustments were quadratic, but with different maximum points depending on the copper application site (Figure 5b). The highest net photosynthetic rate occurred with the application of 2.03 and 3.86 $\mathrm{kg} \mathrm{ha}^{-1} \mathrm{Cu}$, reaching to 18.28 and $16.37 \mu \mathrm{mol} \mathrm{m}^{-2} \mathrm{~s}^{-1}$ with foliar and soil application, respectively (Figure $5 \mathrm{~b}$ ).

The photochemical efficiency of photosystem II has similar quadratic adjustments between the forms of application of copper, with the doses of 0.53 and $0.1 \mathrm{~kg} \mathrm{ha}^{-1}$ copper providing the highest rates, 0.73 and 0.75 , with soil and foliar application, respectively (Figure 5c).

Soil fertilization leads to the highest grain yields in common bean, regardless of copper dose, being on average $12 \%$ higher than those obtained with foliar fertilization (Table 4). The analysis of the effect of the interaction between application site and copper dose shows quadratic adjustments in both situations, in which the foliar and soil application of 2.07 and $2.00 \mathrm{~kg}$ $\mathrm{ha}^{-1}$ copper, respectively, lead to the highest yields, reaching 1661.69 and $1858.03 \mathrm{~kg} \mathrm{ha}^{-1}$ (Figure 6).

Figure 6. Common bean grain yield as a function of different managements and doses of copper. * - significant at $5 \%$ probability by the F-test.

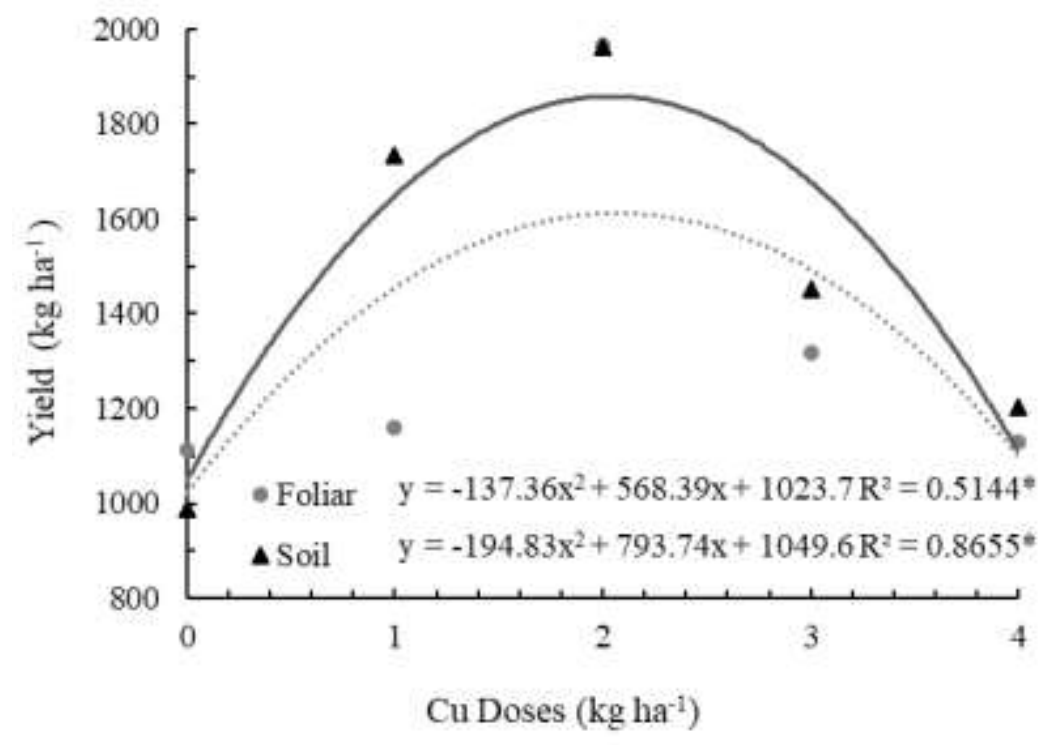

Source: Authors.

Figure 7 shows the results of differential profits for soil and foliar application of $\mathrm{Cu}$ in relation to the doses applied. We note that soil application of $\mathrm{Cu}$ provided positive differential profits for all doses a, with the dose of $2 \mathrm{~kg} \mathrm{Cu}^{-1}$ providing the greatest return, US\$ $581.96 \mathrm{ha}^{-1}$. However, when we evaluated the effect of foliar $\mathrm{Cu}$ application on differential profit, we observed that only the doses of 2 and $3 \mathrm{~kg} \mathrm{Cu} \mathrm{ha}^{-1}$ provided positive increases, with the dose of $2 \mathrm{~kg} \mathrm{Cu} \mathrm{ha}^{-1}$ providing the best differential profit, US\$ $487.50 \mathrm{ha}^{-1}$. 
Figure 7. Economic analysis of common bean as a function of different managements and doses of copper.

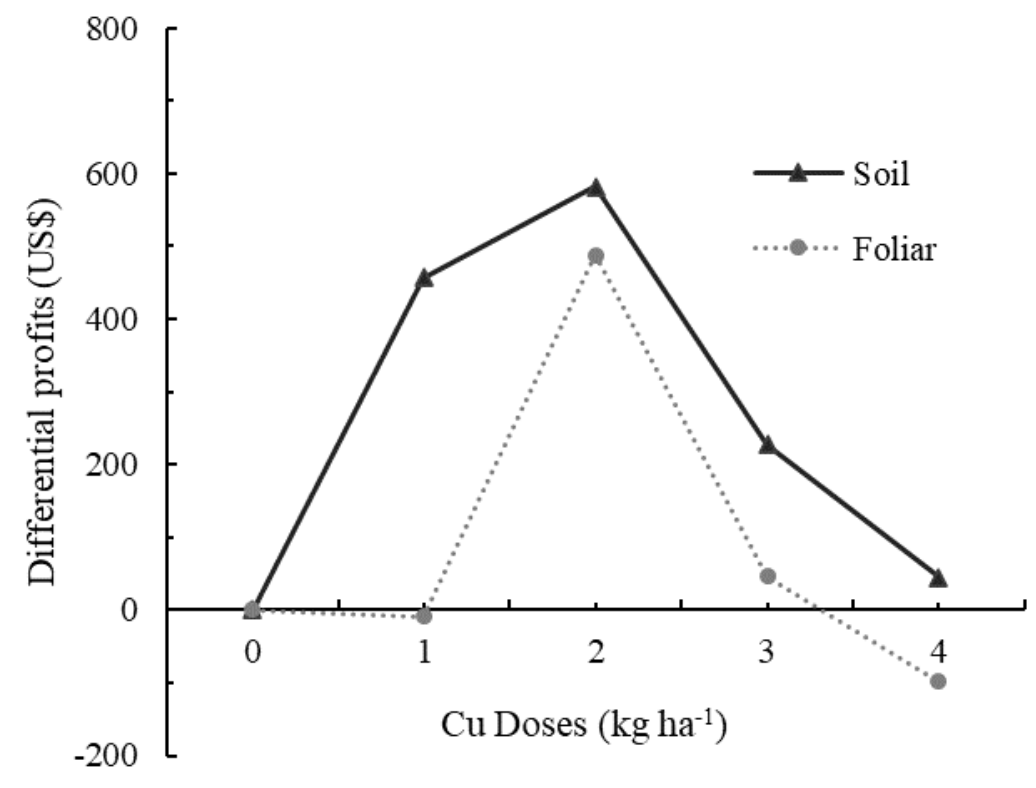

Source: Authors.

\section{Discussion}

Although the literature shows high copper use efficiency through foliar fertilization for bean crop (Karamanos et al., 2004; Hummes et al., 2019), the present study demonstrates the opposite. In this case, copper had a high affinity to adsorb into soil particles, and then become unavailable to plants uptaking. Yruela (2005) explained that pH is the key point due to $\mathrm{Cu}$ dependence to be available and mobile. The same authors' speeches are based on the acidity which tends to dissolve copper and decrease the strength of ion binding to colloids. Furthermore, according to Boone et al. (2012), the copper source used $\left(\mathrm{Cu}_{2} \mathrm{SO}_{4} \cdot 5 \mathrm{H}_{2} \mathrm{O}\right)$ in this present study is highly soluble, especially in an acidic medium (Justel et al., 2015).

The physicochemical characterization of the soil in the present study points to high sand content and high acidity (Table 1). This means less capacity of copper fixation in the clay minerals of the soil, improving nutrient availability in the soil solution and thus facilitating its absorption by plants. Copper uptake by plants occurs preferably via mass flow (Prado, 2008); however, root interception can also occur (Chen et al., 2005; Chaves et al., 2010; Brunetto et al., 2016). Therefore, copper application close to the roots may favor absorption, making it more efficient (Chaves et al., 2010; Sun et al., 2019). According to Kempers (1989), metallic elements such as copper can also be transported in the soil through a phenomenon known as diffusion, which is influenced by a concentration gradient in the soil. The splitting of soil copper fertilization can increase the ion-root contact by maintaining $\mathrm{Cu}$ concentration in the rhizosphere during the entire growing season, reflecting the increase in the leaf $\mathrm{Cu}$ content of plants, as occurred in the present study (Table 2) at 25 DAE.

In the present study, all the aforementioned factors that favor copper absorption improved grain yield due to the increase in $\mathrm{Cu}$ absorption capacity. Thus, grain yield reached a maximum point close to that indicated in the literature, that is, 2 $\mathrm{kg} \mathrm{ha}^{-1}$ (Karamanos et al., 2004; Chen et al., 2005; Chaves et al., 2010; Lange et al., 2016; Sun et al., 2019; Zabotto et al., 2020).

The evaluation of the $\mathrm{N}$ content in the plant becomes a good indicator to understand the greater or lesser absorption of $\mathrm{Cu}$ by the plant. High levels of soil nitrogen can limit $\mathrm{Cu}$ absorption by plants, especially when the doses are greater than 100 $\mathrm{kg} \mathrm{ha}^{-1} \mathrm{~N}$. In this case, plants are likely to prioritize the absorption of $\mathrm{N}$ over $\mathrm{Cu}$, in addition to delaying the redistribution of $\mathrm{Cu}$ (which is already slow) from the older leaves to the growing points. Moreover, plants can also fix Cu in protein compounds 
in the roots, contributing to its low availability for the plant (Singh et al., 2016). The results show the lack of a pronounced effect in this regard since $\mathrm{N}$ levels in the plant changed depending on the greater or lesser supply of $\mathrm{Cu}$ to the soil.

In the present study, copper fertilization did not affect leaf nitrogen levels in common bean, even with the application of $80 \mathrm{~kg} \mathrm{ha}^{-1} \mathrm{~N}$ for cultivation. Corroborating this behavior, soil fertilization led to higher levels of $\mathrm{Cu}$ in the plant, mainly in the evaluation carried out at $25 \mathrm{DAE}$. This fertilization also reduced RCI values with increasing $\mathrm{Cu}$ doses, as can be seen in Figure 2. Studies by Xiong et al. (2006) point out that $\mathrm{Cu}$ negatively affects $\mathrm{N}$ levels in plants, which may reduce leaf chlorophyll content. Eser and Aydemir, (2016) report that the decline in the relative chlorophyll index of plants subjected to stress caused by $\mathrm{Cu}$ toxicity can be attributed to the dampened activity of protochlorophyllide reductase, which contributes to the synthesis of chlorophyll and to the increase in chlorophyllase activity, enzyme that degrades chlorophyll molecules (Gadallah \& El-Enany, 1999).

Even though initially having $1.7 \mathrm{mg} \mathrm{dm}^{-3} \mathrm{Cu}$ in the arable layer of soil (0-20 $\mathrm{cm}$ deep) (Table 1$)$ and providing up to 4 $\mathrm{kg} \mathrm{ha}^{-1} \mathrm{Cu}$, the absorption of the nutrient occurred with a quadratic adjustment. This indicates the possible occupation of $\mathrm{Cu}$ up to the limit of availability of its loads in the sites of binding to the soil colloids, making the exchangeable fraction of the element subject to root absorption and/or element loss in the system by leaching (Ceretta et al., 2010). According to (Singh et al., 2016), both sandy and clayey soils may show $\mathrm{Cu}$ deficiency. However, this deficiency takes place by different mechanisms: by leaching in sandy soils and by adsorption in clayey soils. In addition to granulometry, the organic matter content, the $\mathrm{pH}$, and high levels of phosphorus and nitrogen can influence copper availability for plants. Similarly, Fageria et al. (2008) also observed increases in leaf copper content with increasing rates of $\mathrm{Cu}$ supply to the soil, corroborating the present study.

According to Grohskopf et al. (2016), $\mathrm{Cu}$ accumulation in the leaf tissues of beans directly depends on the availability of this nutrient in the soil. In this sense, organic matter (O.M.) stands out as the main source of copper in the soil, as it has a greater specific surface, with negative net charge, being able to form organic chelates (Plaza et al., 2013). According to NóvoaMuñoz et al. (2008), soils with low and medium levels of O.M. $\left(<25 \mathrm{mg} \mathrm{kg}^{-1}\right)$ require the application of higher doses of this micronutrient since it is stored in low quantities and can even be fixed to clay minerals of the soil, being retained and not available to plants. Therefore, the maintenance of adequate levels of organic matter in the soil becomes important, as it favors the predominance of the exchangeable fraction of the element.

All of these factors that hinder greater efficiency in copper supply to plants from soil fertilization have driven studies and the adoption of foliar fertilization practices, especially with micronutrients such as copper. With the direct application of nutrient-containing fertilizers to the leaves, the nutrients are deposited in the leaf blade and then pass through the cuticle, a structurally complex waxy layer, reaching the interior of the plant cell. When studying the absorption of urea and glucose, Schönherr (2006) concluded that liquids can penetrate through cuticular pores up to $0.9 \mathrm{~nm}$ in diameter.

Similarly, $\mathrm{Cu}$ levels in the leaf tissues also increased with the greater supply of $\mathrm{Cu}$ to the plants, even in the evaluation performed at 45 DAE. Notwithstanding, this evaluation showed lower concentrations in relation to the those obtained at 25 DAE. Some factors help to explain this behavior, the first being the effect of dilution, since the absorption rate may have decreased with the advance in the crop cycle and, as a second effect, the possible redistribution of $\mathrm{Cu}$ from old leaves (sources) to young and reproductive parts (drains), even with the restricted mobility of $\mathrm{Cu}$.

According to Ribeiro et al. (2012), the bean crop has good copper absorption capacity and can redistribute this element to the grains, even if it is present at low amounts in the soil. The authors mention the export of $9.80 \mathrm{mg} \mathrm{kg}^{-1}$ to the grains in a treatment without $\mathrm{Cu}$ supply and with an initial content of $1.5 \mathrm{mg} \mathrm{dm}^{-3}$. It is noteworthy that the highest levels of $\mathrm{Cu}$ were obtained with the soil application of this nutrient, indicating greater efficiency in its use by plants in relation to foliar application. Other studies also reported this behavior (Chen et al., 2005; Nóvoa-Muñoz et al., 2008; Chaves et al., 2010; 
Brunetto et al., 2016; Grohskopf et al., 2016; Lange et al., 2016).

Transpiration (E) in plants is indicative of physiological stress (Hasanuzzaman et al., 2017; Medina et al., 2019) and can be considered a mechanism of resistance to copper absorption (Fu et al., 2015). Fu et al. (2015) report that this resistance may be one explanation for the effect of copper doses on the transpiration parameter in common bean. Foliar $\mathrm{Cu}$ application increased transpiration rates in comparison to treatments with soil application of the element (Table 3). However, regardless of the site of copper application to plants, the increase in copper supply increased the transpiration rates of common bean (Fig ure 4), indicating stress induction at high doses of the element, as reported by Fu et al. (2015); Chandra and Kang (2016); Rucińska-Sobkowiak (2016).

Physiological parameters correlate with each other (Reddy \& Zhao, 2005; Chandra \& Kang, 2016; RucińskaSobkowiak, 2016; Mathobo et al., 2017; Flores et al., 2019). This effect is evident in the present study, especially with foliar $\mathrm{Cu}$ application (Figure 5), in which the behavior of the physbiological variables (Gs, A, and Fv Fm ${ }^{-1}$ ) was similar. There are indications that the amount of copper applied $\left(4 \mathrm{~kg} \mathrm{ha}^{-1}\right)$ exceeds the requirements of the plants, causing stress due to the high absorption rate. The increase in transpiration rate increases water loss to the atmosphere in plants that receive high doses of $\mathrm{Cu}$ via soil, mainly due to the increase in stomatal conductance (Paula et al., 2015).

In general, the results obtained suggest the $\mathrm{Cu}$ dose close to $2 \mathrm{~kg} \mathrm{ha}^{-1}$ as a limit to the onset of plant stress in soils with $1.7 \mathrm{mg} \mathrm{dm}^{-3} \mathrm{Cu}$. Some studies indicate that this limit is tenuous, after which the nutrient starts to be toxic to plant metabolism (Yruela, 2005; Fu et al., 2015; Chandra \& Kang, 2016). Stomata are the main route of gas exchange between the atmosphere and the interior of the photosynthetic apparatus, which makes their monitoring of great importance to understand the physiological processes of plants (Amaral et al., 2006).

Studies indicate that the permeability of cuticles to ions from foliar fertilization depends on abiotic factors similar to stomatal uptake. Moreira and Moraes (2019) suggest that stomata and cuticles play an important role in nutrient absorption; however, stomatal penetration appears to be more complex and depends on more abiotic factors than cuticular penetration. Thus, under natural conditions, stomatal penetration is slower than cuticular penetration. Copper fertilization increased stomatal conductance, regardless of application site; notwithstanding, foliar fertilization was more efficient in this regard.

Copper increased the net photosynthetic rate regardless of application site. This effect is due to the fact that copper indirectly correlates with photosynthesis, as it participates in the activation and formation of several enzymes (Cakmak, 2000; Kerbauy, 2004; Hänsch \& Mendel, 2009; Marschner, 2012). Some important enzymes dependent on copper metabolism are plastocyanin, which acts during photosynthesis as an electron donor for the chlorophyll reaction center of photosystem I, and cytochrome oxidase, which participates in the respiratory electron transport chain (Hänsch \& Mendel, 2009). Uribe \& Stark (1982) found that $\mathrm{Cu}^{2+}$ deficiency affects the reactions of chloroplasts by restricting electron transport, consequently altering the essential factor in energy transfer from photosynthesis. According to Malavolta (2006); Hänsch and Mendel (2009); Marschner (2012), Cu mainly affects photosynthetic electron flow, respiration, symbiotic nitrogen fixation, and $\mathrm{N}$ and $\mathrm{S}$ assimilation by plants, whether in electron transport or as an enzyme activator.

The results presented in Table 3 demonstrate that both the soil and foliar fertilization of common bean, regardless of the fertilizer dose applied, did not influence $\mathrm{Fv} \mathrm{Fm}^{-1}$, which averaged 0.77 for both cases. However, the interaction between the application site and the applied doses demonstrates that soil fertilization reaches a minimum Fv Fm ${ }^{-1}$ of 0.73 when applied via leaf, with a subsequent increase with increasing doses until reaching 0.79 (Figure 5c). Moreover, soil copper fertilization increases the photochemical efficiency of photosystem II with quadratic adjustment until reaching 0.79 with the application of the highest dose. The photochemical efficiency of photosystem II $\left(\mathrm{Fv} \mathrm{Fm}^{-1}\right)$ indicates whether the plant is experiencing any type of stress; therefore, its increase indicates a better use and conversion of light energy (Casierra-Posada et al., 2011). The proportion of open reaction centers of photosystem II comprises the quantum energy in the process of conversion to chemical 
energy, which reflects the photosynthetic efficiency and the light use efficiency of the plant (Mathobo et al., 2017). When plants are subjected to environmental stresses, the $\mathrm{Fv} \mathrm{Fm}^{-1}$ ratio can vary in a range below 0.75 . When the photosynthetic apparatus is intact, the values vary between 0.75 and 0.85 in plants under optimal environmental conditions (Suassuna et al., 2010; Silva et al., 2015). Thus, based on the results obtained for Fv Fm${ }^{-1}$, the application of copper as copper sulphate improved the resistance of common bean to photoinhibitory stress.

The application of high $\mathrm{Cu}$ concentrations negatively affects plant growth. In this situation, plants show fewer leaves, lower chlorophyll content, and shorter roots, which consequently reduce biomass and grain yield (Xiong et al., 2006). High soil $\mathrm{Cu}$ concentrations significantly reduce plant and crop yield (Rizwan et al., 2016), and Cu toxicity affects mainly root growth and morphology, since this element is absorbed and accumulated in the roots, being hardly translocated to the shoots of plants (Rehman et al., 2019). Figure 2 shows that, for both forms of fertilization, copper doses higher than $2 \mathrm{~kg} \mathrm{ha}^{-1}$ are harmful to common bean yield. Nonetheless, $\mathrm{Cu}$ toxicity did not lead to visual symptoms in common bean, both with soil and foliar application up to $4.00 \mathrm{~kg} \mathrm{ha}^{-1}$.

In cereals, $\mathrm{Cu}$ deficiency is popularly known as white tip disease since it causes chlorosis in the youngest parts of the plants. Its deficiency also causes male sterility, delay in flowering, and grain yield loss (Singh et al., 2016). Thus, adequate supply of copper to plants improves grain yield, as occurred in the present study (Figure 6). In addition to the metabolic effects triggered by the presence of $\mathrm{Cu}^{2+}$ in plants, the micronutrient is also used in leaf solutions to combat fungal and bacterial diseases, contributing to plant resistance against biotic stress (Sonmez et al., 2006; Cumplido-Nájera et al., 2019).

Studies on copper fertilization showed a $62 \%$ increase in wheat yield with the application of $1.5 \mathrm{mg} \mathrm{kg}^{-1}$ copper via soil (Kumar et al., 2009). Moreira and Moraes (2019) demonstrated that fertilization with $4 \mathrm{~kg} \mathrm{ha}^{-1}$ copper increased soybean yield by $12.5 \%$ in comparison to control treatments (without copper-containing fertilizer). These results corroborate the present study (Figure 6), presenting increases in grain yield up to the dose of $2 \mathrm{~kg} \mathrm{ha}^{-1}$, regardless of application site. It is noteworthy that the soil application of copper increased grain yield in relation to foliar application.

The physiological apparatus of plants behaved as a function of grain yield due to the lower physiological stress of gas exchange (Figure 5). Stressed plants significantly increase the production of reactive oxygen species (ROS), including hydrogen peroxide $\left(\mathrm{H}_{2} \mathrm{O}_{2}\right)$ (Hu et al., 2009), and their accumulation can be toxic to plants. Hydrogen peroxide is the main reactive oxygen species, which activates molecules for the induction of defence genes. This ROS is also involved in the polymerization of proteins that make up the cell wall and in the stimulus for the production of antioxidative enzymes (Eukasik et al., 2012). Due to its redox nature, $\mathrm{Cu}$ increases the generation of $\mathrm{H}_{2} \mathrm{O}_{2}$ which, in addition to the aforementioned functions, is a molecule that can modulate plant growth and development (Nazir et al., 2019). This molecule also activates the tolerance of plants to stress conditions (Zhou et al., 2018), improves photosynthetic activity (Khan et al., 2016; Noctor et al., 2018), and increases stomatal conductance (Deng et al., 2012; Y. Ma \& Niu, 2017). These effects resulting from the good copper nutrition of plants can increase crop yield, as occurred in the present study (Figure 6).

When performing economic analysis in relation to soil and foliar application of $\mathrm{Cu}$ for the common bean crop, we observe that, when we use soil application, all doses provide positive differential profit, with the highest (US\$ $581.96 \mathrm{ha}^{-1}$ ) being obtained with use of $2 \mathrm{~kg} \mathrm{Cu} \mathrm{ha}^{-1}$. However, when evaluating the effect of foliar $\mathrm{Cu}$ application for the common bean crop, the doses of 2 and $3 \mathrm{~kg} \mathrm{Cu} \mathrm{ha}^{-1}$ were only that provided financial return, with the dose of $2 \mathrm{~kg} \mathrm{ha}^{-1}$ providing the highest differential profit, approximately US $\$ 487.50 \mathrm{ha}^{-1}$ (Figure 7).

Regarding sprays for nutrient supply, inclusion in operating costs is necessary, and in the present study, the value spent on each spray increased production costs of common beans in US\$ $15.51 \mathrm{ha}^{-1}$, having as reference the prices practiced in 2020. In production systems of the third crop seasons (with irrigation) of common beans that have high technology, it is common to use agricultural pesticides to fight pests and diseases (Miorini et al., 2017; Teixeira et al., 2019), besides foliar 
fertilization, a growing practice in recent years (Xiaoli et al., 2020).

The $\mathrm{Cu}$ source used in the present study can be associated with other foliar fertilizers and/or pesticides (Ma et al., 2011), which can reduce operational costs of application (US\$ $15.51 \mathrm{ha}^{-1}$ ), providing feasible gains by foliar $\mathrm{Cu}$ application of doses of 2 and $3 \mathrm{~kg} \mathrm{ha}^{-1}$, with differential profits of US\$ 503.01 and 62.03 per hectare, respectively, without the additional cost of spraying. However, we highlight that soil $\mathrm{Cu}$ application provides the best financial return, reaching US\$581.96 ha ${ }^{-1}$ with use of $2 \mathrm{~kg} \mathrm{Cu} \mathrm{ha}^{-1}$.

\section{Conclusion}

Soil copper application is more efficient regarding the nutrient absorption and use by the plant, leading to grain yield increases of $12 \%$ in relation to foliar application, regardless of the applied dose.

The dose of $2 \mathrm{~kg} \mathrm{ha}^{-1} \mathrm{Cu}$ promotes the best net photosynthetic rate and grain yield in common bean. With the foliar and soil application of copper at this dose, grain yield reached about 1,660 and 1,858 $\mathrm{kg} \mathrm{ha}^{-1}$, respectively.

The dose of $2 \mathrm{~kg} \mathrm{Cu} \mathrm{ha}^{-1}$ provided the best differential profit, reaching US\$ $581.96 \mathrm{ha}^{-1}$ and US\$ $503.01 \mathrm{ha}^{-1}$ for soil and foliar application, respectively.

\section{Acknowledgments}

The authors would like to thank the funding provided by the Coordination of Superior Level Staff Improvement (CAPES) and National Council for Science and Technology (CNPq). AFA and AMB would like to thank CAPES for the funds provided from the SD (National Program of Social Demand). RAF would like to thank CNPq for the PQ funds process number 306329/2019-0.

\section{References}

Alvares, C. A., Stape, J. L., Sentelhas, P. C., de Moraes Gonçalves, J. L., \& Sparovek, G. (2013). Köppen’s climate classification map for Brazil. Meteorologische Zeitschrift, 22(6), 711-728. https://doi.org/10.1127/0941-2948/2013/0507

Alves, B. J. R., Smith, K. A., Flores, R. A., Cardoso, A. S., Oliveira, W. R. D., Jantalia, C. P., Urquiaga, S., \& Boddey, R. M. (2012). Selection of the most suitable sampling time for static chambers for the estimation of daily mean N 20 flux from soils. Soil Biology and Biochemistry, 46, 129-135. https://doi.org/10.1016/j.soilbio.2011.11.022

Amaral, J. A. T. do, Rena, A. B., \& Amaral, J. F. T. do. (2006). Crescimento vegetativo sazonal do cafeeiro e sua relação com fotoperíodo, frutificação, resistência estomática e fotossíntese. Pesquisa Agropecuaria Brasileira, 41(3), 377-384. https://doi.org/10.1590/s0100-204x2006000300002

Barbosa Filho, M. P., Cobucci, T., Fageria, N. K., \& Mendes, P. N. (2008). Determinação da necessidade de adubação nitrogenada de cobertura no feijoeiro irrigado com auxílio do clorofilômetro portátil. Ciencia Rural, 38(7), 1843-1848. https://doi.org/10.1590/S0103-84782008000700007

Barbosa, J. C., \& Maldonado Júnior, W. (2015). AgroEstat: Sistema para análises estatísticas de ensaios agronômicos. Faculdade de Ciências Agrárias e Veterinárias UNESP.

Boone, C., Gervais, J. A., Luukinen, B., Buhl, K., \& Stone, D. (2012). Copper Sulfate Technical Fact Sheet. National Pesticide Information Center.

Brunetto, G., Bastos de Melo, G. W., Terzano, R., Del Buono, D., Astolfi, S., Tomasi, N., Pii, Y., Mimmo, T., \& Cesco, S. (2016). Copper accumulation in vineyard soils: Rhizosphere processes and agronomic practices to limit its toxicity. Chemosphere, 162 , $293-307$. https://doi.org/10.1016/j.chemosphere.2016.07.104

Brunetto, G., Comin, J. J., Miotto, A., de Moraes, M. P., Sete, P. B., Schmitt, D. E., Gatiboni, L. C., de Melo, G. W. B., \& Morais, G. P. (2018). Copper and zinc accumulation, fractionation and migration in vineyard soils from Santa Catarina State, Brazil. Bragantia, 77(1), 141-151. https://doi.org/10.1590/16784499.2016391

Cakmak, I. (2000). Tansley review no. 111: Possible roles of zinc in protecting plant cells from damage by reactive oxygen species. New Phytologist, 146(2), 185-205. https://doi.org/10.1046/j.1469-8137.2000.00630.x

Carvalho, C. S., \& Fernandes, M. N. (2019). Effects of copper toxicity at different pH and temperatures on the in vitro enzyme activity in blood and liver of fish, Prochilodus lineatus. Molecular Biology Reports, 46(5), 4933-4942. https://doi.org/10.1007/s11033-019-04944-y

Casaroli, D., Rodrigues, T. R., Martins, A. P. B., Evangelista, A. W. P., \& Júnior, J. A. (2018). Rainfall and evapotranspiration patterns in Goiânia, GO. Revista Brasileira de Meteorologia, 33(2), 247-256. https://doi.org/10.1590/0102-7786332004 
Casierra-Posada, F., Peña-Olmos, J. E., \& Ulrichs, C. (2011). Crecimiento y eficiencia fotoquímica del fotosistema II en plantas de fresa (Fragaria sp.) afectadas por la calidad de la luz: Implicaciones agronómicas. Actual Divulgacion Científica, 14(2), 43-53.

Ceretta, C. A., Girotto, E., Lourenzi, C. R., Trentin, G., Vieira, R. C. B., \& Brunetto, G. (2010). Nutrient transfer by runoff under no tillage in a soil treated with successive applications of pig slurry. Agriculture, Ecosystems and Environment, 139(4), 689-699. https://doi.org/10.1016/j.agee.2010.10.016

Cesar, G., \& Grando, N. (2006). O uso de micronutrientes na maximização da produção. Visão Agrícola, 5, 24-26.

Chandra, R., \& Kang, H. (2016). Mixed heavy metal stress on photosynthesis, transpiration rate, and chlorophyll content in poplar hybrids. Forest Science and Technology, 12(2), 55-61. https://doi.org/10.1080/21580103.2015.1044024

Chaves, L. H. G., Mesquita, E. F. de, Araujo, D. L. de., \& França, C. P. de. (2010). Crescimento, distribuição e acúmulo de cobre e zinco em plantas de pinhão-manso. Revista Ciência Agronômica, 41(2), 167-176. https://doi.org/10.1590/s1806-66902010000200001

Chen, Y. X., Yuan, P. W., Lin, Q., \& Yong, M. L. (2005). Effect of copper-tolerant rhizosphere bacteria on mobility of copper in soil and copper accumulation by Elsholtzia splendens. Environment International, 31(6), 861-866. https://doi.org/10.1016/j.envint.2005.05.044

CONAB. (2020). Acompanhamento da Safra Brasileira de grãos. In Companhia Nacional de Abastecimento.

Cumplido-Nájera, C. F., González-Morales, S., Ortega-Ortíz, H., Cadenas-Pliego, G., Benavides-Mendoza, A., \& Juárez-Maldonado, A. (2019). The application of copper nanoparticles and potassium silicate stimulate the tolerance to Clavibacter michiganensis in tomato plants. Scientia Horticulturae, 245(245), 82-89. https://doi.org/10.1016/j.scienta.2018.10.007

Da, I., Mistura, S., \& Sociedade, E. D. A. (2011). Sigma-Aldrich. 1907, 1-6.

Deng, X. P., Cheng, Y. J., Wu, X. B., Kwak, S. S., Chen, W., \& Eneji, A. E. (2012). Exogenous hydrogen peroxide positively influences root growth and exogenous hydrogen peroxide positively influences root growth and metabolism in leaves of sweet potato seedlings. Australian Journal of Crop Science, $6(11), 1572-1578$.

Eser, A., \& Aydemir, T. (2016). The effect of kinetin on wheat seedlings exposed to boron. Plant Physiology and Biochemistry, 108, 158-164. https://doi.org/10.1016/j.plaphy.2016.06.024

Fageria, N. K., Baligar, V. C., \& Li, Y. C. (2008). The role of nutrient efficient plants in improving crop yields in the twenty first century. Journal of Plant Nutrition, 31(6), 1121-1157. https://doi.org/10.1080/01904160802116068

FAO. (2014). World reference base for soil resources 2014. International soil classification system for naming soils and creating legends for soil maps. In World Soil Resources Reports No. 106. https://doi.org/10.1017/S0014479706394902

Ferreira, Manuel Evaristo Cruz, M. C. P. (1991). Micronutrientes na agricultura (M. C. P. Ferreira, Manuel Evaristo Cruz (Ed.)). POTAFOS/CNPq.

Flores, R. A., da Cunha, P. P., Damin, V., Abdala, K. de O., Maranhão, D. D. C., dos Santos, M. M., Neto, L. R. G., Donegá, M. C., \& Rodrigues, R. A. (2019). Physiological quality and grain production of Phaseolus vulgaris (cv. BRS Pérola) using boron (B) application under irrigatation system. Australian Journal of Crop Science, 13(4), 520-528. https://doi.org/10.21475/ajcs.19.13.04.p1383

Flores, R. A., Rodrigues, R. A., da Cunha, P. P., Damin, V., Arruda, E. M., de Oliveira Abdala, K., \& Donegá, M. C. (2018). Grain yield of phaseolus vulgaris in a function of application of boron in soil. Journal of Soil Science and Plant Nutrition, 18(1), 144-156. https://doi.org/10.4067/S0718-95162018005000701

Flores, R. A., Silva, R. G. da, Cunha, P. P. da, Damin, V., Abdala, K. de O., Arruda, E. M., Rodrigues, R. A., \& Maranhão, D. D. C. (2017). Economic viability of Phaseolus vulgaris (BRS Estilo) production in irrigated system in a function of application of leaf boron. Acta Agriculturae Scandinavica Section B: Soil and Plant Science, 67(8), 697-704. https://doi.org/10.1080/09064710.2017.1329454

Flores, R. A., Silva Junior, A. R., Damin, V., Arruda, E. M., Prado, E. R., \& Araújo, C. E. (2017). Nutrition and Production of Phaseolus vulgaris (BRS estilo) Following Boron Application on Soil. Communications in Soil Science and Plant Analysis, 48(12), 1409-1416. https://doi.org/10.1080/00103624.2017.1358744

Floss, E. L. (2008). Fisiologia das plantas cultivadas: o estudo do que está por trás do que se vê. UPF.

Fu, L., Chen, C., Wang, B., Zhou, X., Li, S., Guo, P., Shen, Z., Wang, G., \& Chen, Y. (2015). Differences in copper absorption and accumulation between copper-exclusion and copper-enrichment plants: A comparison of structure and physiological responses. Plos One, 10(7), 1-18. https://doi.org/10.1371/journal.pone.0133424

Gadallah, M. A. A., \& El-Enany, A. E. (1999). Role of kinetin in alleviation of copper and zinc toxicity in Lupinus termis plants. Plant Growth Regulation, 29(3), 151-160. https://doi.org/10.1023/A:1006245628188

Grohskopf, M. A., Correa, J. C., Cassol, P. C., Nicoloso, R. S., \& Fernandes, D. M. (2016). Copper and zinc forms in soil fertilized with pig slurry in the bean crop | Formas de cobre e zinco no solo adubado com dejeto suíno na cultura do feijão. Revista Brasileira de Engenharia Agricola e Ambiental, 823-829. https://doi.org/10.1590/1807-1929/agriambi.v20n9p823-829

Hänsch, R., \& Mendel, R. R. (2009). Physiological functions of mineral micronutrients (Cu, Zn, Mn, Fe, Ni, Mo, B, Cl). Current Opinion in Plant Biology, 12(3), 259-266. https://doi.org/10.1016/j.pbi.2009.05.006

Hasanuzzaman, M., Davies, N. W., Shabala, L., Zhou, M., Brodribb, T. J., \& Shabala, S. (2017). Residual transpiration as a component of salinity stress tolerance mechanism: A case study for barley. BMC Plant Biology, 17(1), 1-12. https://doi.org/10.1186/s12870-017-1054-y

Hu, Y., Ge, Y., Zhang, C., Ju, T., \& Cheng, W. (2009). Cadmium toxicity and translocation in rice seedlings are reduced by hydrogen peroxide pretreatment. 
Plant Growth Regulation, 59(1), 51-61. https://doi.org/10.1007/s10725-009-9387-7

Hummes, A. P., Bortoluzzi, E. C., Tonini, V., da Silva, L. P., \& Petry, C. (2019). Transfer of copper and zinc from soil to grapevine-derived products in young and centenarian vineyards. Water, Air, and Soil Pollution, 230(7), 1-11. https://doi.org/10.1007/s11270-019-4198-6

IBEGE-PAM. (2020). Pesquisa Agrícola Municipal. https://sidra.ibge.gov.br/Tabela/1612

Justel, F. J., Claros, M., \& Taboada, M. E. (2015). Solubilities and physical properties of saturated solutions in the copper sulfate + sulfuric acid + seawater system at different temperatures. Brazilian Journal of Chemical Engineering, 32(3), 629-635. https://doi.org/10.1590/0104-6632.20150323s00003393

Karamanos, R. E., Pomarenski, Q., Goh, T. B., \& Flore, N. A. (2004). The effect of foliar copper application on grain yield and quality of wheat. Canadian Journal of Plant Science, 84(1), 47-56. https://doi.org/10.4141/P03-090

Kempers, L. J. T. M. (1989). A thermodynamic theory of the Soret effect in a multicomponent liquid. The Journal of Chemical Physics, 90(11), 6541-6548. https://doi.org/10.1063/1.456321

Kerbauy, G. B. (2004). Fisiologia Vegetal. Editora Guanabara Koogan S.A.

Khan, M. I. R., Khan, N. A., Masood, A., Per, T. S., \& Asgher, M. (2016). Hydrogen peroxide alleviates nickel-inhibited photosynthetic responses through increase in use-efficiency of nitrogen and sulfur, and glutathione production in mustard. Frontiers in Plant Science, 7, 1-20. https://doi.org/10.3389/fpls.2016.00044

Kumar, V., Brainard, D. C., \& Bellinder, R. R. (2009). Effects of spring-sown cover crops on establishment and growth of hairy galinsoga (galinsoga ciliata) and four vegetable crops. HortScience, 44(3), 730-736. https://doi.org/10.21273/hortsci.44.3.730

Lange, B., Pourret, O., Meerts, P., Jitaru, P., Cancès, B., Grison, C., \& Faucon, M. P. (2016). Copper and cobalt mobility in soil and accumulation in a metallophyte as influenced by experimental manipulation of soil chemical factors. Chemosphere, 146, 75-84. https://doi.org/10.1016/j.chemosphere.2015.11.105

Łukasik, I., Goławska, S., \& Wójcicka, A. (2012). Effect of cereal aphid infestation on ascorbate content and ascorbate peroxidase activity in triticale. Polish Journal of Environmental Studies, 21(6), 1937-1941.

Ma, J. F., Yamaji, N., \& Mitani-Ueno, N. (2011). Transport of silicon from roots to panicles in plants. Proceedings of the Japan Academy Series B: Physical and Biological Sciences, 87(7), 377-385. https://doi.org/10.2183/pjab.87.377

Ma, Y., \& Niu, J. (2017). The role of phytosphingosine-1-phosphate (Phyto-S1P) and its relationships with cytosolic pH and hydrogen peroxide ( $\left.\mathrm{H}_{2} \mathrm{O}_{2}\right)$ during stomatal closure by darkness in broad bean. South African Journal of Botany, 108, 237-242. https://doi.org/10.1016/j.sajb.2016.11.002

Malavolta., E. (2006). Manual de nutrição mineral de plantas. Editora Agronômica Ceres Ltda.

Marschner. (2012). Mineral nutrition of higher plants. (3rd ed.) Elsevier. https://doi.org/10.1016/C2009-0-63043-9

Mathobo, R., Marais, D., \& Steyn, J. M. (2017). The effect of drought stress on yield, leaf gaseous exchange and chlorophyll fluorescence of dry beans (Phaseolus vulgaris L.). Agricultural Water Management, 180, 118-125. https://doi.org/10.1016/j.agwat.2016.11.005

Medina, S., Vicente, R., Nieto-Taladriz, M. T., Aparicio, N., Chairi, F., Vergara-Diaz, O., \& Araus, J. L. (2019). The plant-transpiration response to vapor pressure deficit (VPD) in durum wheat is associated with differential yield performance and specific expression of genes involved in primary metabolism and water transport. Frontiers in Plant Science, , 1-19. https://doi.org/10.3389/fpls.2018.01994

Mesquita, M. A. M., da Silveira, P. M., Leandro, W. M., Flores, R. A., \& Maranhão, D. D. C. (2018). DRIS standards for nutritional evaluation of Phaseolus vulgaris in Cerrado, Goiás state, Brazil. Australian Journal of Crop Science, 12(2), 274-280. https://doi.org/10.21475/ajcs.18.12.02.pne766

Miorini, T. J. J., Raetano, C. G., \& Everhart, S. E. (2017). Control of white mold of dry bean and residual activity of fungicides applied by chemigation. Crop Protection, 94, 192-202. https://doi.org/10.1016/j.cropro.2016.12.023

Moreira, A., \& Moraes, L. A. C. (2019). Soybean response to copper applied to two soils with different levels of organic matter and clay. Journal of Plant Nutrition, 42(18), 2247-2258. https://doi.org/10.1080/01904167.2019.1655039

Nazir, F., Hussain, A., \& Fariduddin, Q. (2019). Hydrogen peroxide modulate photosynthesis and antioxidant systems in tomato (Solanum lycopersicum L.) plants under copper stress. Chemosphere, 230, 544-558. https://doi.org/10.1016/j.chemosphere.2019.05.001

Noctor, G., Reichheld, J. P., \& Foyer, C. H. (2018). ROS-related redox regulation and signaling in plants. Seminars in Cell and Developmental Biology, 80, $3-$ 12. https://doi.org/10.1016/j.semcdb.2017.07.013

Noronha, J. F. (1987). Projetos agropecuários: administração financeira, orçamento e viabilidade econômica (2 th). Atlas.

Nóvoa-Muñoz, J. C., Arias-Estévez, M., Pérez-Novo, C., \& López-Periago, J. E. (2008). Diffusion-induced changes on exchangeable and organic bound copper fractions in acid soil samples enriched with copper. Geoderma, 148(1), 85-90. https://doi.org/10.1016/j.geoderma.2008.09.009

Oliveira, T. C., Silva, J., Salgado, F. H. M., Sousa, S. A., \& Fidelis, R. R. (2012). Eficiência e resposta à aplicação de fósforo em feijão comum em solos de cerrado. Revista Verde de Agroecologia e Desenvolvimento Sustentável, 7(1), 16-24.

Paula, L. de S., Silva, B. do C., de Pinho, W. C. S., Barbosa, M. A. M., Guedes-Lobato, E. M. S., Segura, F. R., Batista, B. L., Júnior, F. B., \& Lobato, A. K. da S. (2015). Silicon (Si) ameliorates the gas exchange and reduces negative impacts on photosynthetic pigments in maize plants under Zinc (Zn) toxicity. Australian Journal of Crop Science, 9(10), 901-908. 
Pires, M. V., Filla, V. A., Coelho, A. P., Leal, T., Víctor, J., Bettiol, T., \& Lemos, L. B. (2020). Desempenho agronômico e qualitativo de cultivares de feijoeiro dos grupos comerciais carioca e especial na época de inverno. Reivista de la Faculdade de Agronomia, $L$

a Plata 119, 1-8. https://doi.org/10.24215/16699513e046

Plaza, C., Courtier-Murias, D., Fernández, J. M., Polo, A., \& Simpson, A. J. (2013). Physical, chemical, and biochemical mechanisms of soil organic matter stabilization under conservation tillage systems: A central role for microbes and microbial by-products in C sequestration. Soil Biology and Biochemistry, 57, 124-134. https://doi.org/10.1016/j.soilbio.2012.07.026

Prado, R. de M. (2008). Nutrição de Plantas. In Editora Unesp (1 th, Vol. 1).

Reddy, K. R., \& Zhao, D. (2005). Interactive effects of elevated $\mathrm{CO}_{2}$ and potassium deficiency on photosynthesis, growth, and biomass partitioning of cotton. Field Crops Research, 94(2-3), 201-213. https://doi.org/10.1016/j.fcr.2005.01.004

Rehman, M., Liu, L., Wang, Q., Saleem, M. H., Bashir, S., Ullah, S., \& Peng, D. (2019). Copper environmental toxicology, recent advances, and future outlook: a review. Environmental Science and Pollution Research, 26(18), 18003-18016. https://doi.org/10.1007/s11356-019-05073-6

Ribeiro, N. D., Maziero, S. M., Prigol, M., Nogueira, C. W., Rosa, D. P., \& Possobom, M. T. D. F. (2012). Mineral concentrations in the embryo and seed coat of common bean cultivars. Journal of Food Composition and Analysis, 26(1-2), 89-95. https://doi.org/10.1016/j.jfca.2012.03.003

Rizwan, M., Ali, S., Qayyum, M. F., Ibrahim, M., Zia-ur-Rehman, M., Abbas, T., \& Ok, Y. S. (2016). Mechanisms of biochar-mediated alleviation of toxicity of trace elements in plants: a critical review. Environmental Science and Pollution Research, 23(3), 2230-2248. https://doi.org/10.1007/s11356-015-5697-7

Román, R. A. A., Cortez, J. W., Oliveira, J. R. G. di., \& Ferreira, M. da C. (2019). Pulverização de fungicida na cultura da soja em função de ponta e volumes de aplicação. Parte 1: Avaliação de cobertura. IV Sintag - Simpósio Internacional de Tecnologia de Aplicação de Agrotoxicos, 4, 25-28.

Rosolem, C. A., \& Marubayashi, O. M. (1994). Nutrição e adubação do feijoeiro. Informações Agronômicas, 68, 1-16.

Rucińska-Sobkowiak, R. (2016). Water relations in plants subjected to heavy metal stresses. Acta Physiologiae Plantarum, 38(11). https://doi.org/10.1007/s11738-016-2277-5

Santos, H. G. dos, Jacomine, P. K. T., Anjos, L. H. C. dos, Oliveira, V. A. de, Lumbreras, J. F., Coelho, M. R., Almeida, J. A. de, Araujo Filho, J C de Oliveira, J. B. de, \& Cunha, T. J. F. (2018). Brazilian Soil Classification System (5 th). Embrapa.

Santos, L. T. S., Vespucci, I. L., \& Nunes, M. P. C. (2020). Aplicação adicional de bioestimulantes em estádio reprodutivo de feijão comum (Phaseolus vulgaris 1.) com intuito de acréscimo na produtividade. Pubvet, 14(3), 1-7. https://doi.org/10.31533/pubvet.v14n3a533.1-7

Schönherr, J. (2006). Characterization of aqueous pores in plant cuticles and permeation of ionic solutes. Journal of Experimental Botany, 57(11), 2471-2491. https://doi.org/10.1093/jxb/erj217

Shabbir, Z., Sardar, A., Shabbir, A., Abbas, G., Shamshad, S., Khalid, S., Natasha, Murtaza, G., Dumat, C., \& Shahid, M. (2020). Copper uptake, essentiality, toxicity, detoxification and risk assessment in soil-plant environment. Chemosphere, 259, 127436. https://doi.org/10.1016/j.chemosphere.2020.127436

Silva, A. J., Nascimento, C. W., da Gouveia-Neto, A. S., \& Silva Junior, E. A. (2015). Efeitos do silício no alívio da toxicidade de arsênio em plantas de milho. Revista Brasileira de Ciencia Do Solo, 39(1), 289-296. https://doi.org/10.1590/01000683rbcs20150176

Silva, F. C. da. (2009). Manual of chemical analyzes of soils, plants and fertilizers (2 th). Embrapa Informação Tecnológica.

Silva, F. O., \& Wander, A. E. (2013). O feijão-comum no Brasil: passado, presente e futuro. Documentos Embrapa Arroz e Feijão, $287,1-63$.

Singh, J. S., Jain, D. K., Bhushan, A B. (2016). Fertilization : A Review. January 2013, 258-320. https://doi.org/10.13140/RG.2.1.1629.3844

Sonmez, S., Kaplan, M., Sonmez, N. K., Kaya, H., \& Uz, I. (2006). High level of copper application to soil and leaves reduce the growth and yield of tomato plants. Scientia Agricola, 63(3), 213-218. https://doi.org/10.1590/S0103-90162006000300001

Soratto, R. P., de Carvalho, M. A. C., \& Arf, O. (2004). Teor de clorofila e produtividade do feijoeiro em razão da adubação nitrogenada. Pesquisa Agropecuaria Brasileira, 39(9), 895-901. https://doi.org/10.1590/s0100-204x2004000900009

Sousa, D. M. G. de., \& Lobato, E. (2004). Cerrado: Correction of soil and fertilization. In Embrapa Cerrados (2 th).

Souza, H. A. de, Hernandes, A., Romualdo, L. M., Rozane, D. E., Natale, W., \& Barbosa, J. C. (2011). Folha diagnóstica para avaliação do estado nutricional do feijoeiro. Revista Brasileira de Engenharia Agricola e Ambiental, 15(12), 1243-1250. https://doi.org/10.1590/s1415-43662011001200005

Suassuna, J. F., Melo, A. S., Sousa, M. S. S., Costa, F. S., Fernandes, P. D., Pereira, V. M., \& Brito, M. E. B. (2010). Desenvolvimento e eficiência fotoquímica em mudas de híbrido de maracujazeiro sob lâminas de água. Bioscience Journal, 4(1).

Sun, Q., Li, T., Alva, A. K., \& Li, Y. C. (2019). Mobility and fractionation of copper in sandy soils. Environmental Pollutants and Bioavailability, 31(1), 1823. https://doi.org/10.1080/09542299.2018.1558114

Teixeira, P. C., Donagemma, G. K., Fontana, A., \& Teixeira, W. G. (Eds.). (2017). Manual de métodos de análise de solo (3 th). Embrapa.

Teixeira, P. H., Lima, R. C., Bonicontro, B. F., Mendes, O. L., Soares, B. A., Carneiro, J. E. S., Paula Júnior, T. J., \& Vieira, R. F. (2019). Management of white mold in common bean using partial resistance and fungicide applications. Crop Protection. https://doi.org/10.1016/j.cropro.2019.104867

Uribe, E. G., \& Stark, B. (1982). Inhibition of photosynthetic energy conversion by cupric ion. Plant Physiology, 69(5), 1040-1045. https://doi.org/10.1104/pp.69.5.1040 
Research, Society and Development, v. 10, n. 4, e42710414234, 2021

(CC BY 4.0) | ISSN 2525-3409 | DOI: http://dx.doi.org/10.33448/rsd-v10i4.14234

Xiaoli, N., Hanmi, Z., Xiukang, W., Tiantian, H., Puyu, F., Ting, L., Na, Z., \& Dongxue, Y. (2020). Changes in root hydraulic conductance in relation to the overall growth response of maize seedlings to partial root-zone nitrogen application. Agricultural Water Management, 229. https://doi.org/10.1016/j.agwat.2019.105839

Xiong, Z. T., Liu, C., \& Geng, B. (2006). Phytotoxic effects of copper on nitrogen metabolism and plant growth in Brassica pekinensis Rupr. Ecotoxicology and Environmental Safety, 64(3), 273-280. https://doi.org/10.1016/j.ecoenv.2006.02.003

Yruela, I. (2005). Copper in plants. Brazilian Journal of Plant Physiology, 17(1), 145-156. https://doi.org/10.1590/s1677-04202005000100012

Zabotto, A. R., França, W. S., Domingos, M., Rinaldi, M. C. S., Kanashiro, S., Ferreira, M. L., \& Tavares, A. R. (2020). Copper accumulation and distribution in two arboreal species of the Atlantic Forest. Floresta e Ambiente, 27(1), 1-7. https://doi.org/10.1590/2179-8087.002719

Zhou, L., Hou, H., Yang, T., Lian, Y., Sun, Y., Bian, Z., \& Wang, C. (2018). Exogenous hydrogen peroxide inhibits primary root gravitropism by regulating auxin distribution during Arabidopsis seed germination. Plant Physiology and Biochemistry, 1(28) 126-133. https://doi.org/10.1016/j.plaphy.2018.05.014 